NBER WORKING PAPER SERIES

\title{
HORSES AND RABBITS? OPTIMAL DYNAMIC CAPITAL STRUCTURE FROM SHAREHOLDER AND MANAGER PERSPECTIVES
}

\author{
Nengjiu Ju \\ Robert Parrino \\ Allen M. Poteshman \\ Michael S. Weisbach \\ Working Paper 9327 \\ http://www.nber.org/papers/w9327
NATIONAL BUREAU OF ECONOMIC RESEARCH
1050 Massachusetts Avenue
Cambridge, MA 02138
November 2002

\begin{abstract}
We would like to thank participants at seminars at Arizona State University, DePaul University, University of Illinois, Koc University, the New York Federal Reserve Bank, Princeton University, University of South Carolina, University of Texas at Austin, and Washington State University for helpful suggestions. The views expressed herein are those of the authors and not necessarily those of the National Bureau of Economic Research.

(C) 2002 by Nengjiu Ju, Robert Parrino, Allen M. Poteshman, and Michael S. Weisbach. All rights reserved. Short sections of text, not to exceed two paragraphs, may be quoted without explicit permission provided that full credit, including $\odot$ notice, is given to the source.
\end{abstract}


Horses and Rabbits? Optimal Dynamic Capital Structure

from Shareholder and Manager Perspectives

Nengjiu Ju, Robert Parrino, Allen M. Poteshman, and Michael S. Weisbach

NBER Working Paper No. 9327

November 2002

JEL No. G32, G33, H250

\section{$\underline{\text { ABSTRACT }}$}

This paper examines optimal capital structure choice using a dynamic capital structure model that is calibrated to reflect actual firm characteristics. The model uses contingent-claim methods to value interest tax shields, allows for reorganization in bankruptcy, and maintains a long-run target debt/equity ratio by refinancing maturing debt. Using this model we calculate optimal capital structures in a realistic representation of the traditional 'tradeoff' model. In contrast to previous research, the resulting optimal capital structures do not imply that firms tend to use too little leverage in practice. We also estimate the costs borne by a firm whose capital structure deviates from its optimal, 'target' debt/equity ratio. The costs of moderate deviations are relatively small, suggesting that a policy of adjusting leverage only when it deviates substantially from a target debt/equity ratio is likely to be reasonable for most firms.

Nengjiu Ju

Department of Finance

Smith School of Business

University of Maryland

College Park, MD 20742

nju@rhsmith.umd.edu

Allen M. Poteshman

Department of Finance

College of Commerce

and Business Administration

University of Illinois

Champaign, IL 6182

poteshma@uiuc.edu
Robert Parrino

Deprtment of Finance

McCombs School of Business

University of Texas at Austin

Austin, TX 78712-1179

parrino@mail.utexas.edu

Michael S. Weisbach

Department of Finance

College of Commerce

and Business Administration

University of Illinois

Champaign, IL 61820

and NBER

weisbach@uiuc.edu 


\section{Horses and Rabbits? Optimal Dynamic Capital Structure from Shareholder and Manager Perspectives}

\section{Introduction}

A central issue in corporate finance research is the question of why, despite the large tax advantage enjoyed by debt, actual firms have fairly low leverage ratios. This question motivated much of the early research on agency theory (Jensen and Meckling, 1976; Myers, 1977), important work on information asymmetries (Myers and Majluf, 1984), three American Finance Association presidential addresses (Miller, 1977; Myers, 1984; and Leland, 1998), and some well-regarded recent research (Graham, 2000). The consensus view underlying this vast literature is that bankruptcy costs alone are too small to offset the value of tax shields, and that other factors, such as agency costs, must be introduced into the cost-benefit analysis to explain actual capital structures. Miller (1977, p. 264) memorably characterizes the discrepancy by comparing the trade-off between tax gains and bankruptcy costs as "like the recipe for the fabled horse-and-rabbit stew - one horse and one rabbit".

The underlying logic of this widespread view is that, while tax shields are large (about 9.7 percent of firm value according to Graham, 2000), expected bankruptcy costs are small because they are incurred infrequently and represent only a small fraction of firm value when they are incurred. Yet, the tradeoff theory does not contain any predictions about the relative level of tax shields and bankruptcy costs; rather, it states that at the margin, adding a small amount of debt will not change firm value. Evaluating the extent to which Miller's intuition captures the essence of the capital structure problem requires a formal model, calibrated to reflect actual data.

This paper estimates optimal capital structure from a calibrated continuous-time contingent claim model. The model is based on the dynamic framework of Ju (2001), which corresponds to a traditional tradeoff approach insofar as the only explicitly modeled factors affecting capital structure are tax shields and bankruptcy costs. In our model, the manager of an unlevered firm undertakes a fairly priced debt/equity swap, in which the manager selects the fraction of equity to be exchanged for debt with the 
objective of maximizing either the per-share value of the firm's equity or his own utility. The swap that maximizes the per-share value of equity is optimal from the shareholders' perspective, and the swap that maximizes the manager's utility is optimal from his perspective.

We find that the optimal debt to total capital ratio is 14.42 percent when we maximize share value for a firm that is calibrated to be similar to the median firm on the Standard and Poors' Computstat database. In comparison, the median firm in Compustat had a debt to total capital ratio of 22.6 percent in 2000. The fact that our estimate of the optimal predicted debt to total capital ratio is below the median value of 22.6 percent implies that, contrary to the dominant view in the literature, the typical firm is overleveraged. For, example, a number of recent papers (e.g., Leland, 1994; Leland and Toft, 1996;

Goldstein, Ju, and Leland, 2001), that calibrate continuous-time contingent claim models and characterize optimal leverage as the capital structure at which adding a small amount of debt does not change firm value, predict leverage ratios that are substantially higher than those observed in practice.

Several features of our approach cause our model to predict lower levels of debt in the optimal capital structure than the previous continuous-time contingent claim models. First, the model is dynamic in the sense that finite maturity debt is repeatedly issued and re-financed upon maturity at a pre-specified target debt to total capital ratio. The opportunity to increase debt in the future, if firm value increases, lowers the optimal initial leverage ratio because firms issue debt less aggressively than they would if the debt level could not be adjusted with changes in firm value (e.g., Leland, 1994 and Leland and Toft, 1996). Second, in some previous models (e.g., Leland, 1994), debt is perpetual so firms only make taxdeductible interest payments. In contrast, issuers of debt in our model make both tax-deductible interest payments and non-deductible principal payments. An implication of this difference is that interest deductions are relatively less valuable in our model, leading firms to use less leverage ex ante. Finally, like the other continuous-time contingent claim models, we specify the value of the unlevered assets as an 
exogenous process. ${ }^{1}$ The volatility of changes in this process has often been calibrated to 0.20 (Leland, 1994 and Leland and Toft, 1996). In contrast, we calibrate the volatility of changes in the unlevered value of the firm to about 0.38 , which produces lower optimal leverage ratios. We calibrate the volatility to this higher number, because it results in our model producing credit spreads and bankruptcy recovery rates that match levels observed in practice. $^{2}$

The costs associated with deviations from the optimal capital structure are as important as the optimal debt/value ratio itself. We also calculate firm value as a function of capital structure, and our estimates indicate that the impact on firm value of moderate deviations from optimal capital structure is small. For example, for any debt to total capital ratio between 10.3 percent and 19.4 percent, an adjustment to the optimal level of 14.42 percent would increase firm value by less than 0.5 percent for the typical firm. Insofar as the transaction costs for adjusting capital structure to its target level exceed the potential increase in firm value, the optimal policy may be to allow the firm's capital structure to deviate substantially from its target debt/total capital ratio. Our estimates suggest that it probably makes sense to allow the capital structure to deviate by at least ten percentage points before recapitalizing the firm. Such a policy is consistent with the recent evidence reported by Welch (2002), who documents that firms do not regularly recapitalize following shocks to their equity values. Our model thus suggests that when similar firms receive differing shocks to their equity values, they will not find it optimal to adjust their capital structures back to the target level. Our model is therefore consistent with the well-documented empirical regularity of otherwise similar firms having very different capital structures from one another.

\footnotetext{
${ }^{1}$ The early capital structure models of Kane, Marcus, and McDonald $(1984,1985)$ and Fischer, Heinkel, and Zechner (1989) specify the optimally levered value of the firm as an exogenous process. While this modeling choice yields some important insights, it is not a convenient approach in the present context. Specifying the optimally levered value of the firm as an exogenous process makes it difficult to directly analyze the impact of tax shields and bankruptcy costs on capital structure decisions.

${ }^{2}$ We also independently compute this asset volatility directly using data for firms in the Compustat database and get a median value of about 0.28 . As explained below, this estimate is downwardly biased, so the value computed using the Compustat data appears to be consistent with our baseline estimate of 0.38 . It should also be noted that while the 0.30 equity volatility that is used to guide others' choice of unlevered asset volatility (e.g., Leland and Toft, 1996) may be sensible for an equity index, it is too low for the equity of a typical individual firm. For example, our estimate of the median individual firm equity volatility over the time period when we preformed our calibration is 0.685 .
} 
We next introduce agency conflicts into this framework by calculating the value of the swap that, instead of maximizing the value of a share of stock, maximizes the utility of a potential manager. We assume the manager has a constant relative risk aversion utility function with a risk-aversion parameter of 2, owns 0.32 percent of the company's stock, has at-the-money options on 0.38 percent of the company's stock, and has non-firm wealth equal to the value of his shares. When the swap is chosen to maximize this utility function, the optimal leverage drops to 11.25 percent of firm value.

We perform numerical comparative statics to evaluate the sensitivity of the results on optimal capital structure to the major parameters of the model. Not surprisingly, corporate tax rates, bankruptcy costs, and the ability of debtholders to force the firm into bankruptcy all impact optimal capital structure ratios.

We also calibrate the model to estimate the optimal capital structure for 15 actual firms. For 10 of these 15 firms, the predicted stock-price maximizing leverage ratio is less than the firm's actual leverage ratio, and for all of the 15 firms the predicted utility-maximizing leverage ratio is less than actual leverage ratio. In general, the model is able to predict, within a reasonable degree of error, the leverage observed at firms that have relatively small to typical levels of debt, but substantially underestimates the level of debt observed at highly levered firms.

Overall, the results in this paper suggest that the tradeoff model performs reasonably well in predicting capital structures for firms with typical levels of debt. Certainly, the "horse and rabbit stew" analogy seems inappropriate - actual capital structures appear to be somewhat higher than those predicted by this model. Our model implies that important determinants of capital structure include the underlying risk of the firm's assets, the ability of debtholders to force default for a given level of firm value, the debt maturity, as well as the incremental costs conditional on default. Our ability to measure these variables is quite limited using current econometric methods; a better understanding of their relative importance can advance our understanding of capital structure choices, and potentially improve the financing choices of actual firms. 
The rest of this paper is organized as follows: Section 2 describes the model in detail. Section 3 explains how we calibrate the model to reflect current market data. Section 4 discusses the implications of the calibrated model, and Section 5 concludes. Technical details are discussed in the Appendix.

\section{A Dynamic Model of Capital Structure}

The models that we use are based on Ju $(1998,2001)$. In these models, the firm issues debt with a maturity of $T$, which pays a continuous, constant (tax-deductible) coupon. The manager's wealth at time zero is divided between non-firm wealth and his stake in the firm, which consists of equity shares and standard European call options on the firm's shares, which expire at time $T_{u}$. The manager cannot sell or hedge his shares or options. For simplicity, it is assumed that the manager's non-firm wealth grows at the risk-free rate, $r$, and is therefore uncorrelated with the value of the manager's stake in the firm. The manager's utility is given by a CRRA utility function defined over his entire wealth. The value process of the firm's assets (i.e., the value of the cash flows from operations) follows geometric Brownian motion.

The model is in continuous time with $0<T_{u}<T$. At time zero the value of the firm's assets is

$V(0)$. Before the swap, the firm's capital consists of $N_{N S}$ shares of stock with a total market value of $E_{N S}(0)=V(0) .{ }^{3}$ The value of the firm's assets, $V(t)$, follows geometric Brownian motion described by:

$$
\frac{d V(t)}{V(t)}=(\mu-\delta) d t+\sigma d Z(t)
$$

where $\mu$ and $\sigma>0$ are constants and $Z(t)$ is a standard Wiener process. The firm liquidates assets at a rate of $\delta$ of the total value of the firm's assets, so that $\delta V(t) d t$ is equal to a time varying dividend

\footnotetext{
${ }^{3}$ The subscript $N S$ refers to quantities before the swap (i.e., no swap) and the subscript $S$ will refer to quantities after the swap is completed.
} 
$\operatorname{div}(t) d t$ paid to equity holders over the time interval $d t$ :

$$
\delta V(t) d t=\operatorname{div}(t) d t
$$

The value of $\delta$ is specified exogenously as a model parameter.

We consider a fair equity for debt swap at time zero that either (1) maximizes the value of a share of equity or (2) maximizes the manager's expected utility at time $T_{u}$. The swap is fair in the sense that the debt is issued at its correct market value. The debt has a face value of $F_{S}$ and has a market value when it is issued at time zero of $D_{S}(0)$. The debt pays a coupon at a constant annualized rate $C_{S}$ which is set so that the debt is priced at par, that is, $F_{S}=D_{S}(0)$. The firm deducts its coupon payments from its taxes at an effective rate $\tau$, and the tax benefit of the debt at time zero has a value of $T B_{S}(0)$. The debt has a protective covenant which specifies that if the firm value, at anytime during the life of the debt $[0, T]$, decreases to an exponential boundary, the firm is forced into bankruptcy. ${ }^{4}$ When this occurs, the stock becomes worthless and the debtholders recover $1-\alpha_{B C}$ of the levered value of the assets. The fraction of the value of the assets not recovered by the debtholders is assumed to be consumed in the bankruptcy process. The bankruptcy boundary is an exponential curve that increases at a rate $g$ and is equal to the face value of debt at time $T$. Consequently, the bankruptcy boundary is described by $F_{S} e^{g(t-T)}$. The bankruptcy costs for the firm are the present value of the expected losses in bankruptcy, and are denoted by $B C_{S}(0)$. After the swap the firm still liquidates assets at a rate of $\delta$ of the total value of the firm's assets, so that $\delta V(t) d t$ equals the sum of the after-tax coupon paid to debt holders $\left[(1-\tau) C_{S} d t\right]$ and a time varying dividend $d i v(t) d t$ paid to equity holders over the time interval $d t$ :

\footnotetext{
${ }^{4}$ Following Black and Cox (1976), we are implicitly assuming that this covenant acts somewhat like the actual covenants seen in bond indentures. The idea is that actual bond covenants are set up to give bondholders the right to seize assets when they are in danger of being lost - this assumption models this right explicitly.
} 


$$
\delta V(t) d t=\left[\operatorname{div}(t)+(1-\tau) C_{S}\right] d t
$$

Note that (3) can require a cash infusion for low $V(t) .^{5}$

We assume that the swap is fully transparent so that the post-swap values of the debt and equity exchanged are equal in magnitude and opposite in sign:

$$
D_{S}(0)=-\left(\frac{N_{S}-N_{N S}}{N_{S}}\right) E_{S}(0) .
$$

At time zero there is an infinite number of fair equity for debt swaps available to the firm. We will analyze two of these. The first swap we consider maximizes the value of a share of equity. That is, it maximizes the quantity, $E_{S}(0) / N_{S}$. The second swap we consider maximizes the manager's expected utility at time $T_{u}$. That is, it maximizes the expected value of the manager's CRRA utility function (which is defined over his total wealth) at time $T_{u}$.

At time zero the manager's stake in the firm consists of $N_{\text {Man }}\left(<N_{N S}\right)$ shares and $N_{\text {Calls }}$ European call options with strike price $K$ that expire at time $T_{u}$. For purposes of computational tractability, we assume that the firm buys the manager's calls from a third party. Hence, if the manager exercises the calls at time $T_{u}$, he buys $N_{\text {Calls }}$ shares from the third party at a price of $N_{\text {Calls }} K$ dollars. We assume that the manager cannot sell or hedge either his shares or his options. In addition, at time zero the manager has $N F W(0)$ dollars of non-firm wealth. For simplicity, this wealth is assumed to grow at the risk-free rate. When the swap is performed in order to maximize the manager's expected utility at time $T_{u}$, this utility is described by

$$
U\left(\text { Wealth }_{T_{u}}\right)=\frac{\left(\text { Wealth }_{T_{u}}\right)^{1-\gamma}-1}{1-\gamma},
$$

\footnotetext{
${ }^{5}$ Though our bankruptcy boundary is exogenous, cash infusion is not uncommon for models with an endogenous boundary (e.g., Leland, 1994).
} 
where $\gamma$ is a risk-aversion parameter and Wealth $_{T_{u}}$ is the manager's total wealth at time $T_{u}$.

The value of the debt, the bankruptcy costs, and the tax benefit of debt are computed from the probability density function for first hitting the exponential bankruptcy boundary. Let $f\left(t^{*} ; V(0), A, g, r, \delta, \sigma\right)$ be the probability density for first hitting a boundary described by $A e^{g t}$ at a time $t^{*}$, where $A$ is a constant, if the variable $V$ initially has a value $V(0)>A$ and follows geometric Brownian motion with drift $r-\delta$ and volatility $\sigma$. In our model, $A$ is the value of the bankruptcy boundary at time zero, so that $A$ is equal to $F_{S} e^{-g T}$. An explicit expression for $f\left(t^{*} ; V(0), A, g, r, \delta, \sigma\right)$ is provided in the Appendix. Next define:

$$
\begin{gathered}
G(T, V(0), A, g, r, \delta, \sigma) \equiv \int_{0}^{T} f\left(t^{*} ; V(0), A, g, r, \delta, \sigma\right) d t^{*}, \\
H(T, V(0), A, g, r, \delta, \sigma) \equiv \int_{0}^{T} e^{-r t^{*}} f\left(t^{*} ; V(0), A, g, r, \delta, \sigma\right) d t^{*},
\end{gathered}
$$

and

$$
I(T, V(0), A, g, r, \delta, \sigma) \equiv \int_{0}^{T} e^{-(r-g) t^{*}} f\left(t^{*} ; V(0), A, g, r, \delta, \sigma\right) d t^{*}
$$

Closed form solutions for these expressions are derived in the Appendix.

Following Leland and Toft (1996), the value of the debt at time zero is the sum of a contribution from the coupon, a contribution from the payment to debtholders if bankruptcy occurs, and the repayment of the face value at time $T$ if bankruptcy does not occur:

$$
\begin{aligned}
D_{S}(0)= & C_{S} \int_{0}^{T} e^{-r t^{*}}\left(1-G\left(t^{*}, V(0), F_{S} e^{-g T}, g, r, \delta, \sigma\right)\right) d t^{*} \\
& +\int_{0}^{T} e^{-r t^{*}}\left(1-\alpha_{B C}\right) \frac{T V_{S}(0)}{V(0)} F_{S} e^{-g\left(T-t^{*}\right)} f\left(t^{*}, V(0), F_{S} e^{-g T}, g, r, \delta, \sigma\right) d t^{*} \\
& +F_{S}\left(1-G\left(T, V(0), F_{S} e^{-g T}, g, r, \delta, \sigma\right)\right) e^{-r T},
\end{aligned}
$$

or 


$$
\begin{aligned}
D_{S}(0)= & \frac{C_{S}}{r}\left(1-\left(1-G\left(T, V(0), F_{S} e^{-g T}, g, r, \delta, \sigma\right)\right) e^{-r T}-H\left(T, V(0), F_{S} e^{-g T}, g, r, \delta, \sigma\right)\right) \\
& +\left(1-\alpha_{B C}\right) \frac{T V_{S}(0)}{V(0)} F_{S} e^{-g T} I\left(T, V(0), F_{S} e^{-g T}, g, r, \delta, \sigma\right) \\
& +F_{S}\left(1-G\left(T, V(0), F_{S} e^{-g T}, g, r, \delta, \sigma\right)\right) e^{-r T}
\end{aligned}
$$

where

$$
T V_{S}(0)=V(0)+T B_{S}(0)-B C_{S}(0)
$$

is the total levered value of the firm at time zero after the swap. If the $T V_{S}(0) / V(0)$ factor were omitted from equation (9), then the debtholders would receive $\left(1-\alpha_{B C}\right)$ of the unlevered value of the assets of the firm upon bankruptcy. The inclusion of this factor implements the modeling decision that upon bankruptcy the debtholders receive $\left(1-\alpha_{B C}\right)$ of the levered value to a healthy firm of the remaining assets. Explicit expressions for $T B_{S}(0)$ and $B C_{S}(0)$ are provided below.

Another modeling decision involves the question of whether the firm should refinance the debt obtained in the swap when it matures. We consider two alternative models: The first is a "static" model, in which the firm does not replace the debt from the swap when it matures, and is therefore financed entirely with equity after time $T$. The second is a "dynamic" model, in which new debt is reissued when old debt matures. Since the dynamic framework seems a priori more appealing, and in fact Ju (1998, 2001) shows that the refinancing assumption can affect corporate financing decisions ex ante, we analyze the dynamic model. Nonetheless, it is convenient to present the solution of the dynamic model in terms of that for the static model that we develop now.

\subsection{The Static Model}

In the static model, when the firm is forced into bankruptcy at time $t^{*}$, the bankruptcy costs are $\alpha_{B C} V\left(t^{*}\right)$. Hence, at time zero the value of the bankruptcy costs are 


$$
B C_{S}(0)=\int_{0}^{T} \alpha_{B C} F_{S} e^{g\left(t^{*}-T\right)} e^{-r t^{*}} f\left(t^{*} ; V(0), F_{S} e^{-g T}, g, r, \delta, \sigma\right) d t^{*}
$$

or

$$
B C_{S}(0)=\alpha_{B C} F_{S} e^{-g T} I\left(T, V(0), F_{S} e^{-g T}, g, r, \delta, \sigma\right)
$$

The tax benefits of debt accrue to the firm as long as it has not gone bankrupt. Consequently, the tax benefits of debt in the static model can be computed by

$$
T B_{S}(0)=\int_{0}^{T} \tau C_{S} e^{-r t^{*}}\left(1-G\left(t^{*}, V(0), F_{S} e^{-g T}, g, r, \delta, \sigma\right)\right) d t^{*}
$$

or

$$
T B_{S}(0)=\frac{\tau C_{S}}{r}\left(1-\left(1-G\left(T, V(0), F_{S} e^{-g T}, g, r, \delta, \sigma\right)\right) e^{-r T}-H\left(T, V(0), F_{S} e^{-g T}, g, r, \delta, \sigma\right)\right)
$$

The value of the equity is equal to the unlevered value of the assets plus the tax benefits of debt minus the bankruptcy costs minus the value of the debt:

$$
E_{S}(0)=V(0)+T B_{S}(0)-B C_{S}(0)-D_{S}(0)
$$

In order to compute the manager's time zero expectation of his utility at time $T_{u}$, let $V^{K}\left(T_{u}\right)$ be the value of the firm's assets at time $T_{u}$ that makes a share of stock worth $K$ at time $T_{u}$. Then the manager's time zero expectation of his utility at time $T_{u}$ is the sum of three components. The first component is a function of the density for the value of the firm's assets being at various levels above $V^{K}\left(T_{u}\right)$ at time $T_{u}$ without having touched the bankruptcy boundary between time zero and time $T_{u}$. The second component is a function of the density for the value of the firm's assets being at various levels below $V^{K}\left(T_{u}\right)$ at time $T_{u}$ without having touched the bankruptcy boundary between time zero and time $T_{u}$. The third component is the utility derived from his non-firm wealth if the bankruptcy boundary is hit. Let $\rho(V(T) ; V(0), T, A, g, \mu, \delta, \sigma)$ be the density function for starting at a value $V(0)>A$ and being 
at $V(T)>A e^{g T}$ at time $T>0$ without ever hitting the boundary $A e^{g t}$ in the interval $t \in[0, T]$ when the $V$ process follows geometric Brownian motion with drift $\mu-\delta$ and volatility $\sigma$. An explicit expression for $\rho(V(T) ; V(0), T, A, g, \mu, \delta, \sigma)$ is presented in the Appendix. Then at time zero, the manager's expectation of his utility at time $T_{u}$ after the swap is given by

$$
\begin{aligned}
\text { Utility }_{S}(0)=\int_{V^{K}\left(T_{u}\right)}^{\infty} U\left\{N F W\left(T_{u}\right)\right. & \left.+\frac{N_{\text {Man }}+N_{\text {Calls }}}{N_{S}}\left[V\left(T_{u}\right)+T B_{S}\left(T_{u}\right)-B C_{S}\left(T_{u}\right)-D_{S}\left(T_{u}\right)\right]-N_{\text {Calls }} K\right\} \\
& \times \rho\left(V\left(T_{u}\right) ; V(0), T_{u}, F_{S} e^{-g T}, g, \mu, \delta, \sigma\right) d V\left(T_{u}\right) \\
+ & \int_{F_{S} e^{-g\left(T-T_{u}\right)}}^{V^{K}\left(T_{u}\right)} U\left\{N F W\left(T_{u}\right)+\frac{N_{\text {Man }}}{N_{S}}\left[V\left(T_{u}\right)+T B_{S}\left(T_{u}\right)-B C_{S}\left(T_{u}\right)-D_{S}\left(T_{u}\right)\right]\right\} \\
& \times \rho\left(V\left(T_{u}\right) ; V(0), T_{u}, F_{S} e^{-g T}, g, \mu, \delta, \sigma\right) d V\left(T_{u}\right) \\
+ & U\left(N F W\left(T_{u}\right)\right) \int_{0}^{T_{u}} f\left(t ; V(0), F_{S} e^{-g T}, g, \mu, \delta, \sigma\right) d t
\end{aligned}
$$

where $V^{K}\left(T_{u}\right)$ satisfies the following equation:

$$
K=\frac{V^{K}\left(T_{u}\right)+T B_{S}\left(T_{u}\right)-B C_{S}\left(T_{u}\right)-D_{S}\left(T_{u}\right)}{N_{S}} .
$$

Note that all terms on the right hand side of equation (18) are a function of $V^{K}\left(T_{u}\right)$.

\subsection{The Dynamic Model}

Next we extend the model to a more realistic dynamic setting. As in the static case, after the swap at time zero the firm has debt outstanding with $T$ years to maturity. Now, however, if the firm has not gone bankrupt at the end of $T$ years, the firm issues new $T$-year debt at time $T$. The new debt has a coupon of $C_{S} V(T) / V(0)$. Similarly, as shown in the Appendix, all other securities will be scaled by a factor of $V(T) / V(0)$, because at time $T$ the firm is identical to itself at time zero except that it is $V(T) / V(0)$ as large. The process of issuing new $T$-year debt when the old debt matures continues indefinitely unless the firm goes bankrupt. 
In this dynamic setting, the price of the debt is still given by equation (10). The firm value, however, will reflect the costs and benefits of the debt issued in the future. In order to determine the total tax benefit and total bankruptcy cost of the current and potential future issues of debt, the following quantity will be useful:

$$
\phi \equiv e^{-r T} E^{Q}\left[\mathbf{1}_{\{\text {Firm does not go bankrupt over [0,T]\} }} \frac{V(T)}{V(0)}\right] .
$$

The indicator function $\mathbf{1}_{\{\text {Firm does not go bankrupt over [0,T]\} }}$ is equal to one if the firm does not go bankrupt over the interval $[0, T]$ and zero otherwise. The expectation is taken over the risk-neutral $Q$ measure. In the Appendix, we show that $\phi$ is given by the following expression:

$$
\phi=e^{-\delta T}\left[N\left(d_{1}\right)-\left(\frac{F_{S} e^{-g T}}{V(0)}\right)^{2\left(1+\left(r-\delta-g-\sigma^{2} / 2\right) / \sigma^{2}\right)} N\left(d_{2}\right)\right]
$$

where

$$
d_{1}=\frac{-\log \left(F_{S} e^{-g T} / V(0)\right)+\left(r-\delta-g+\sigma^{2} / 2\right) T}{\sigma \sqrt{T}}
$$

and

$$
d_{2}=\frac{\log \left(F_{S} e^{-g T} / V(0)\right)+\left(r-\delta-g+\sigma^{2} / 2\right) T}{\sigma \sqrt{T}} .
$$

We also show in the Appendix that the total tax benefit of debt and the total bankruptcy costs are given by

$$
T B_{S}^{\text {Dynamic }}(0)=\frac{T B_{S}(0)}{1-\phi}
$$

and

$$
B C_{S}^{\text {Dynamic }}(0)=\frac{B C_{S}(0)}{1-\phi}
$$

Similar to equation (16), the value of the equity is equal to the unlevered value of the assets plus the tax benefits of debt minus the bankruptcy costs minus the value of the debt: 


$$
E_{S}^{\text {Dynamic }}(0)=V(0)+T B_{S}^{\text {Dynamic }}(0)-B C_{S}^{\text {Dynamic }}(0)-D_{S}(0)
$$

Finally, the manager's utility after the swap in the dynamic model is given by

$$
\begin{aligned}
\text { Utility }_{S}^{\text {Dynamic }}(0)=\int_{V^{K}\left(T_{u}\right)}^{\infty} U\left\{N F W\left(T_{u}\right)+\frac{N_{\text {Man }}+N_{\text {Calls }}}{N_{S}}\left[V\left(T_{u}\right)+T B_{S}^{\text {Dynamic }}\left(T_{u}\right)-B C_{S}^{\text {Dynamic }}\left(T_{u}\right)-D_{S}\left(T_{u}\right)\right]-N_{\text {Calls }} K\right\} \\
\times \rho\left(V\left(T_{u}\right) ; V(0), T_{u}, F_{S} e^{-g T}, g, \mu, \delta, \sigma\right) d V\left(T_{u}\right) \\
+\int_{F_{s} e^{-g\left(T-T_{u}\right)}} U\left\{N F W\left(T_{u}\right)+\frac{N_{\text {Man }}}{N_{S}}\left[V\left(T_{u}\right)+T B_{S}^{\text {Dynamic }}\left(T_{u}\right)-B C_{S}^{\text {Dynamic }}\left(T_{u}\right)-D_{S}\left(T_{u}\right)\right]\right\} \\
\times \rho\left(V\left(T_{u}\right) ; V(0), T_{u}, F_{S} e^{-g T}, g, \mu, \delta, \sigma\right) d V\left(T_{u}\right) \\
+U\left(N F W\left(T_{u}\right)\right) \int_{0}^{T_{u}} f\left(t ; V(0), F_{S} e^{-g T}, g, \mu, \delta, \sigma\right) d t .
\end{aligned}
$$

The details for computing the manager's utility in this dynamic model are provided in the Appendix.

\section{Calibrating the Model}

In choosing the amount of debt that will be swapped for outstanding equity, a face value, $F_{S}$, of

10-year debt (i.e., $T=10$ years) is chosen to maximize either the value of a share of equity or the manager's expected utility one year in the future (i.e., $T_{u}=1$ ). The total value of the firm's assets

before the swap, $V(0)$, is normalized to $\$ 100$, which is divided among 100 shares, each worth $\$ 1$. We

assume that the manager of the firm owns 0.32 of a share of stock and a 1-year exchange traded European call option on an additional 0.38 share. ${ }^{6}$ The strike price for the call option is set equal to the time zero value of a share of equity of the firm before the swap, $\$ 1$. For the base-case, the manager's non-firm wealth is assumed to equal the time-zero value of the shares that the manager owns, $\$ 0.32$. Consistent with the literature, we assume the manager's risk aversion parameter $\gamma$ equals $2{ }^{7}$

Given these assumptions, calibration of the model requires estimates of (1) the risk-free rate, $r$, (2) the effective tax rate, $\tau$, (3) the volatility of the total value of the firm, $\sigma$, (4) the debtholder

\footnotetext{
${ }^{6}$ The manager's stock and option holdings represent the median values for managers at 1,405 firms for which sufficient data to estimate these figures are available for 1999 in the ExecuComp database.

7 See pages 258-260 of Ljungqvist and Sargent (2000) for a discussion of the interpretation of this value.
} 
bankruptcy recovery rate, $\left(1-\alpha_{B C}\right)$, (5) the bankruptcy boundary's exponential growth rate, $g$, (6) the level of dividends, DivRate, paid by the firm, and (7) the drift parameter for the total value of the firm, $\mu$. We estimate these parameters using data from the end of January 2001.

As our estimate of the risk-free rate, we use the rate on 10-year Treasury bonds as of January 30, 2001, as reported in the February 7, 2001 edition of Standard \& Poor's The Outlook. This rate equals 5.22 percent.

To estimate the tax rate used to calculate the tax shields from the debt, we use data on estimated marginal tax rates (before interest expense) provided by John Graham, who constructed these estimates using the approach described in Graham (1996). In particular, for the base case, we assume that the tax rate equals the median marginal tax rate of 34 percent for the 5,519 firms for which 1999 estimates are available.

The volatility of the total value of the firm's assets, $\sigma$, the debtholder bankruptcy recovery rate, $\left(1-\alpha_{B C}\right)$, and the exponential growth rate for the bankruptcy boundary, $g$, are selected to yield an expected recovery rate of 45 percent and a spread over the 10-year Treasury bond rate for the firm's debt that equals 1.90 percent for a firm with the median debt to total capital ratio of 22.62 percent that we observe in Compustat for 2000 . The 45 percent recovery rate is broadly consistent with recovery rates published by Hamilton, Gupton, and Berhault (2001). For the 1981 to 2000 period, Hamilton, Gupton, and Berhault estimate the mean default recovery rates for senior secured bonds, senior unsecured bonds, and subordinated bonds of all ratings to equal 53.9 percent, 47.4 percent, and 32.3 percent, respectively. The 1.90 percent spread over the Treasury bond rate equals the spread for 10-year A-rated corporate debt as of January 30, 2001, as reported in the February 7, 2001 edition of Standard \& Poor's The Outlook. The volatility of the total value of the firm's assets, $\sigma$, is estimated this way to be 0.3802 . This value implies a volatility of the value of the typical firm's equity of 0.4809 . The bankruptcy recovery and bankruptcy boundary growth rates for our base case equal $0.5090\left(\alpha_{B C}=0.4910\right)$ and 3.69 percent $(g=0.0369)$, respectively. 
We set the dividend rate, DivRate, equal to 1.5 percent in the base case. Because this rate is stated as a percentage of the unlevered value of the firm, we use a number that is on the lower end of the 1.5 to 2.0 percent dividend yield paid by public firms at the beginning of 2001 .

We select a value for the drift parameter of the firm, $\mu$, by implementing an argument similar to one provided in Merton (1974). We begin by formally writing the dynamics of the equity's value as

$$
d E=\left(\mu_{E}-\delta_{E}\right) E d t+\sigma_{E} E d Z_{E}
$$

By Ito's lemma and the dynamics of the firm under the physical measure given in equation (1), we can also write the dynamics for $E$ as

$$
d E=\left[\frac{1}{2} \sigma^{2} V^{2} \frac{\partial^{2} E}{\partial V^{2}}+(\mu-\delta) V \frac{\partial E}{\partial V}+\frac{\partial E}{\partial t}\right] d t+\sigma V \frac{\partial E}{\partial V} d Z
$$

Matching the coefficients on the drift components of equations (27) and (28) yields

$$
\mu=\frac{\left(\mu_{E}-\delta_{E}\right) E-\frac{1}{2} \sigma^{2} V^{2} \frac{\partial^{2} E}{\partial V^{2}}-\frac{\partial E}{\partial t}}{V \frac{\partial E}{\partial V}}+\delta .
$$

We set $\mu_{E}$ equal to 0.1122 by assuming an equity risk premium of 6 percent over our risk free rate of 5.22 percent. When the rest of the quantities on the right hand side of equation (29) are computed from the calibrated values for our standardized firm with a debt to total capital ratio of 22.62 percent, the equation yields our base case value for $\mu$ of 10.63 percent.

Panel A of Table I summarizes our parameter choices. These choices are used to derive the set of parameters that are presented in Panel B of Table I.

\section{Optimal Capital Structure}

In our model, each potential capital structure implies different values for tax shields and bankruptcy costs, and ultimately different price distributions for the firm's securities. Beginning with an all equity firm, we identify 'optimal' capital structures from the perspective of shareholders and managers 
for various firm and debt characteristics. The optimal capital structure is defined as the swap that maximizes the objective function in question, conditional on the swap being fair, that is, satisfying equation (4). From the shareholders' perspective, the optimal capital structure is the one that maximizes the post-swap value of each share of equity, and from the manager's perspective, the optimal capital structure is the one that maximizes the manager's expected (post-swap) utility at time $\mathrm{T}_{u}$.

\subsection{Optimal Capital Structures for a Representative Firm}

\subsubsection{The Shareholders' Perspective}

Table II presents estimates of optimal capital structure, from the shareholder perspective, with the model calibrated as discussed above. Each column represents a different level of asset volatility, and the values of all other parameters are as described in Section 3. The optimal capital structure is shown in

Row 1. Optimal leverage levels are clearly very sensitive to asset volatility, equaling 39.56 percent when asset volatility is 13 percent and 7.91 percent when asset volatility is 53 percent. The negative relation between leverage and volatility is consistent with casual empiricism, as well as with studies suggesting that riskier firms do in fact use less leverage (see, for example, Titman and Wessels, 1988; or Rajan and Zingales, 1995).

Given our estimate of asset volatility of 0.3802 , the model does reasonably well at predicting capital structures. For the median firm, the model predicts a debt to total capital ratio of 14.42 percent (equal to book debt of 15.55 divided by book debt of 15.55 plus market value of equity of 92.22). In comparison, for a sample of 2,609 firms for which there is sufficient data on Compustat for 2000, the median debt to total capital ratio (computed as book debt/ book debt plus market equity) equals 22.62 percent. Even with lower values of volatility of 0.28 or 0.33 , the model's predicted leverage ratios are still lower than those for the median firm on Compustat.

Table II highlights the importance of measuring asset volatility when determining capital structures. The procedure we describe above, which picks the model parameters to match the yield spread on the firm's bonds and the expected recovery rate, conditional on reaching bankruptcy, to values 
typically observed in practice, gives a value of 0.3802 for asset volatility. The believability of our model's output (as well as that from other models of capital structure) depends crucially on this parameter choice.

As an independent check on the plausibility of this value for asset volatility, we compute the standard deviation of the change in firm value (estimated as the market value of equity plus the book value of debt) for each of the 1,043 firms for which data are available on Computstat between 1980 and 1999. Calculated in this way, the median estimate of the standard deviation of the change in firm value is 0.285. However, this value is likely to understate the standard deviation of change in asset value at a typical firm for two reasons. First, the procedure used to obtain this estimate is subject to a survivorship bias. Since more volatile firms are more likely to leave the sample than less volatile firms, estimating volatility on the basis of firms that survived throughout the sample period will lead to a lower value than if data for all firms were available. Second, this calculation implicitly assumes that the market value of debt is equal to its book value. Empirically, there is a positive relation between a firm's equity and debt values, so assuming the value of debt is equal to its book value will tend to lower estimated volatilities as well. It is not clear how to quantify precisely the extent to which these two factors lead the Compustatbased estimate of 0.285 to be understated. However, they do suggest that if the estimate of 0.3802 produced by our calibration procedure is too high, it is not too high by much; surely a number greater than 0.30 seems appropriate.

As a final approach to estimating asset volatility, we use daily data on equity prices to compute the standard deviation of equity returns for all firms on CRSP with no missing returns for the three months ending January 2001 (the point in time at which we calibrated our model). The median standard deviation of the equity returns for the firms in this sample is 0.685 . Within the context of our model, an application of Ito's Lemma to this equity volatility implies a standard deviation of asset value changes equal to 0.56 . Although equity returns may have been more volatile than usual during the three months ending in January 2001, the computed standard deviation of 0.56 suggests that the 0.38 value we use is not too high. 


\subsubsection{Why are our Predicted Leverage Ratios so Low?}

Our findings are counter to the common intuition that the tradeoff approach to capital structure choice implies substantially more leverage than is observed in the data. Examination of rows 10 and 11 in Table II, which show the values of bankruptcy costs and tax shields for different levels of asset volatility, suggests one reason our predicted levels may be lower than intuition might suggest. These rows indicate that the average values of the tax shields are substantially higher than the average bankruptcy costs for all of the volatility levels represented in the table. When a firm considers changing its capital structure, the trade-off is not only between 1) the interest tax shields gained (lost) from the debt that is added (retired) and 2) the impact of the change on bankruptcy costs. The change in the expected value of the interest tax shields on the old debt that remains after the capital structure change must also be considered. In other words, the true marginal cost of adding leverage includes not just additional bankruptcy costs, but also the decline in the value of the tax shields from existing debt. ${ }^{8}$

The dynamic nature of our model also leads to lower leverage ratios. The fact that future debt levels will increase with subsequent increases in firm value limits the aggressiveness with which firms in our model issue debt at time zero. In contrast, firms in the static models described in the literature issue debt more aggressively, because they cannot change debt levels in the future even if firm value changes (see, for example, Leland, 1994; and Leland and Toft, 1996).

A third reason our dynamic approach yields lower debt ratios than Leland's (1994) static model concerns the maturity of the debt. Leland's (1994) model has perpetual debt, in which the firm makes deductible interest payments forever. By contrast, in our model, which contains finitely lived debt, the interest payments, but not the principal payments are deductible. As a result, interest deductions are relatively less valuable in our model than in Leland's, leading to a preference for less leverage.

Finally, as discussed above, a particularly important parameter in models of capital structure

\footnotetext{
${ }^{8}$ This effect is similar to one commonly studied in introductory economics classes. The firm's ability to increase value by issuing debt is limited because of the reduction in value of the infra-marginal tax shields in much the same way as a monopolist's ability to increase profits by lowering prices is limited by the loss of profits on infra-marginal units.
} 
choice is $\sigma$, the firm's asset volatility. We have argued above, using three alternative approaches, that the appropriate value of this parameter is greater than 0.30. In contrast, Leland (1994), as well as other related work, such as Leland and Toft (1996), use 0.20 as the estimate of asset volatility. Leland (1994) and Leland and Toft (1996) justify this choice by noting that an asset volatility of 0.20 implies an equity volatility of 0.30 . While 0.30 is a plausible estimate of the volatility of an equity index, it is less than half of our estimate of individual firms equity volatilities, which are relevant for capital structure choices. Nonetheless, while we believe that using a $\sigma$ value of 0.20 is too low given the data, it is still worth noting from Table II, that a $\sigma$ value of 0.20 increases the leverage ratio only to about 30 percent, which is still in the neighborhood of the median firm's leverage of 22.62 percent and lower than the estimates of optimal leverage ratios provided in the literature. ${ }^{9}$

\subsubsection{Measuring the Tradeoff between Tax Shields and Bankruptcy Costs}

The choice of an optimal capital structure as a tradeoff between the debt tax shields and bankruptcy costs is discussed in virtually all introductory corporate finance courses. This tradeoff is featured prominently as a figure in the leading textbooks (for example, see Figure 18.2 on p. 511 of Brealey and Myers, 2000, or Figure 16.1 on p. 404 of Ross, Westerfield and Jaffe, 1999). Because of its widespread coverage in corporate finance curricula, it has surely had some impact on capital structure choice in practice.

To implement a capital structure policy based on this idea, especially when there are transactions costs associated with issuing or retiring securities, one needs to know not just the securities associated with an optimal capital structure, but also the magnitude of the costs of deviating from it. Since we can calculate firm value for any capital structure, not just the optimal one, our approach provides a straightforward way to estimate these costs. To illustrate, Figure 1 presents a graph of firm value as a function of leverage, assuming that all other parameters are at their base case values.

\footnotetext{
${ }^{9}$ In addition, our estimate of the growth rate of the bankruptcy boundary $g$ that comes from our calibration process is $3.69 \%$, which is lower than the $7.5 \%$ used by Ju (2001) and has the effect of lowering implied debt ratios.
} 
Consistent with the numbers reported in Table II, the value-maximizing leverage ratio in Figure 1 is 14.42 percent, at which firm value equals $\$ 107.77$. The graph illustrates that the relation between leverage and firm value is fairly flat around this optimal level. For example, firm value with a leverage ratio of 10.3 percent or 19.4 percent is only 0.5 percent below the maximum value of $\$ 107.77$. For debt to total capital ratios between approximately 7 percent and 25 percent, firm value is still above $\$ 106$. The value of a firm with leverage anywhere in the latter range would increase by less than 1.65 percent if that firm were to return to its optimal capital structure. Given transactions costs and the likely uncertainty about the precise leverage ratio that maximizes firm value, it seems plausible that a reasonable capital structure policy would be to leave capital structure unaltered, so long as debt ratios fluctuate within this 7 percent to 25 percent range.

These estimates help to explain the empirical results of Welch (2002), who documents that firms do not regularly adjust their capital structures to maintain their target levels when equity values change. Figure 1 suggests that such behavior on the part of firms is consistent with the predictions of a simple tradeoff model. It probably is optimal for a firm to adjust its capital structure only when the divergence from the target level is substantial. Over time, as individual firms do not adjust their capital structures in response to idiosyncratic shocks to their equity values, we would expect cross-sectional differences in the capital structures of otherwise similar firms to appear. Such observed differences, which are sometimes used as evidence against theories of optimal capital structure, correspond exactly to what one would expect from a model such as ours.

\subsubsection{The Manager's Perspective}

We next evaluate our model in an agency framework by replacing the assumption that capital structure is chosen to maximize the per share value of equity with the assumption that it is chosen to maximize the manager's utility function. We first assume that the manager maximizes a constant relative risk aversion (CRRA) utility function with a risk aversion parameter of 2 and has 50 percent of his nonoption wealth invested in shares of the firm, with the remainder invested in risk-free assets. As detailed 
in Section 3, our calibration assumes that this stake in the firm equals 0.32 percent of the firm's equity and that the manager has at the money call options to purchase an additional 0.38 percent of the firm's equity. We calculate the optimal capital structure from the manager's perspective by choosing the swap that maximizes the value of his utility function rather than the value of a share of common stock.

The results from this managerial model are presented in Table III. Since the manager is assumed to be risk-averse and the risk of the firm's equity increases with leverage, it is not surprising that the manager prefers less leverage than the shareholders. From a comparison of Tables II and III for each level of risk, it appears that the optimal leverage from manager's perspective is about 3 percentage points lower than from the shareholders' perspective.

\subsection{Sensitivity of Optimal Capital Structure to Model Parameters}

\subsubsection{Tax Rates}

Since the major factor leading to a preference for debt is its tax-deductibility, we expect the model's results to be especially sensitive to tax rates. We compute optimal capital structures (from the shareholder's perspective) as a function of corporate tax rates in Table IV.

Table IV indicates, unsurprisingly, that optimal leverage ratios are positively related to the firm's tax rate. However, this relation appears to be nonlinear and is not as strong as one might expect. With a corporate tax rate of just one percent, the optimal leverage ratio equals 2.24 percent. This ratio rises 5.18 percentage points to 7.42 percent when the tax rate rises to 12 percent. In contrast, at higher tax rates the same 11 percentage point increase in tax rates (from 67 percent to 78 percent) leads to only a 2.27 percentage point increase in leverage, from 22.57 percent to 24.84 percent. Given the other base-case parameters, even very high corporate tax rates do not lead to highly leveraged firms; a tax rate of 78 percent implies an optimal leverage ratio of only 24.8 percent.

\subsubsection{Bankruptcy Boundary}

An important element of our model is that the firm is assumed to default if it hits a pre-specified bankruptcy boundary. The idea underlying this assumption is that most publicly traded debt contains 
covenants enabling debtholders to force default when the value of the firm is sufficiently low. In our model, the parameter $g$ represents the steepness of this boundary, so that a lower $g$ increases the likelihood that the firm defaults given poor performance. Intuitively, $g$ can be thought of as a negative function of the strength of the debt covenants. It is not clear conceptually how we expect this variable to be related to the shareholders' optimal leverage: Stronger debtholder rights make debt more attractive allowing debt to be issued at lower interest rates. Whether these lower interest rates are sufficient to compensate shareholders for the increased bankruptcy probabilities is not obvious.

Table V presents estimates of the optimal capital structure as a function of $g$. The results in this Table indicate that optimal leverage is a positive function of $g$. As the rights of debtholders to force default increase, firms find it optimal to use less leverage. Thus, it appears that the direct effect of a lower $g$ through increased bankruptcy probabilities is more than sufficient to offset the indirect effect of lower interest rates.

\subsubsection{Costs Conditional on Reaching Bankruptcy}

The bankruptcy cost parameter in our model, $\alpha_{B C}$, represents the proportional value lost to bankruptcy costs conditional on hitting the default boundary. We examine the sensitivity of optimal capital structure to this parameter in Table VI.

Not surprisingly, leverage is negatively related to bankruptcy costs. With $\alpha_{B C}$ equal to 10 percent, the optimal leverage ratio is 24.84 percent, compared to 14.30 percent with $\alpha_{B C}$ of 50 percent. However, the relation is relatively weak. While one might expect that as $\alpha_{B C}$ approaches zero, the firm will become extremely highly leveraged, the results in Table VI show that when $\alpha_{B C}$ declines to 10 percent, the leverage ratio only increases to 24.84 percent. These results from Tables V and VI suggest that the threshold at which the debtholders can force the firm into bankruptcy is likely to be as important as the magnitude of the value that is consumed in the bankruptcy process. Perhaps this finding should not be surprising since what affects financing decisions are expected bankruptcy costs at the time they are 
made, and bondholders' rights clearly affect expected bankruptcy costs through their impact on bankruptcy probabilities. Yet, in most textbook discussions of the effect of bankruptcy on capital structure, incremental costs conditional on bankruptcy are discussed at length, while the rights of debtholders to force bankruptcy are not usually emphasized. ${ }^{10}$

\subsection{Model Estimates for Individual Firms}

In addition to estimating the model using parameters for a typical firm, we examine its ability to predict the capital structures observed in a sample of 15 actual firms, five firms from each of three industries - wholesale distribution, beer and wine manufacturing, and paper and allied products. The volatility for each firm is estimated, using the model, by computing the volatility that yields the observed spread between each firm's actual current cost of debt and the yield on Treasury Bonds. The resulting volatility values range from 27.67 percent to 71.98 percent with a median value of 34.34 percent. The stock and option holdings for the individual CEO's are from the 2000 proxy statements filed by the sample firms with the SEC.

Table VII reports the estimated asset volatility, actual leverage, and estimated leverage, both value maximizing and utility maximizing, for each of the 15 sample firms. The striking feature of these results is that, while the model appears to do a good job of predicting leverage for firms with relatively little to typical levels of debt, such as Tessco Technologies, Audiovox, Grainger, and Kimberly-Clark, it substantially underestimates leverage for firms with large amounts of debt. The fact that the model tends to underestimate rather than overestimate leverage for these individual firms is once again counter to the usual intuition that tax shields are far too large to be offset by bankruptcy costs.

\footnotetext{
${ }^{10}$ To the extent that these rights are endogenous choices because of voluntarily adopted covenants rather than exogenous consequences of the legal system, they should be modeled as a choice variable for the firm, instead of as exogenous parameter as we do here. Expanding the model in this way would be a useful direction for future research.
} 


\section{Conclusion}

This paper considers a model of optimal capital structure in which the major forces affecting firms' financing decisions are corporate taxes and bankruptcy costs. As such, this model incorporates effects that have been discussed at great length in the corporate finance literature since Modigliani and Miller (1963). The model contains a number of features designed to capture key elements of the capital structure decision in a realistic way, including contingent-claim valuation of tax shields, a bankruptcy boundary on firm value below which firms default, and a target capital structure at which the firm refinances its debt at maturity. We calculate closed-form solutions for the important variables in this model, calibrate it using recent market data, and solve for the optimal capital structures from both the shareholders' and manager's perspectives.

In contrast to most of the literature since at least Miller (1977), we find that the tradeoff model does not predict that firms are underlevered. For a hypothetical firm constructed to be typical of large, publicly-traded companies, the model predicts a leverage ratio less than the actual sample median - the predicted debt to total capital ratio is 14.42 percent compared to a sample median of 22.6 percent. We also calibrate the model to reflect actual firms and find that the model's failures go in the opposite direction from what is usually presumed. In contrast to the usual intuition, the model suggests that the majority of these firms appear to be overlevered, at least when only taxes and bankruptcy costs are considered.

Our approach allows the computation not only of the optimal capital structure, but also of the cost to a firm of any deviation from the optimum. Our estimates indicate that these costs are relatively small, less than 0.5 percent in value for about a ten-percentage point deviation in leverage. This finding is consistent with recent evidence that adjustments to capital structure in order to maintain a long-run target are relatively rare (Welch 2002).

We also perform a comparative static analysis of the model's underlying parameters, to determine their impact on capital structure choice. One parameter that appears to be particularly important is $g$, the 
slope of the bankruptcy boundary, which we interpret as a measure of the strength of a firm's debt covenants. Our model assumes that this parameter is set exogenously; in a more realistic model of capital structure the strength of these covenants would be an important decision variable in a firm's financing decisions.

By focusing on the tradeoff between tax shields and bankruptcy costs, we do not mean to downplay the importance of other factors. Clearly, the literature has identified agency and information issues as key factors that must be considered in financing decisions. ${ }^{11}$ Rather, our message is that the simple tradeoff framework actually does much better at predicting average leverage levels than has typically been supposed, and should not be dismissed lightly as at least a first-pass way of understanding a firm's financing choices.

We also want to emphasize the usefulness of the approach of taking models seriously and calibrating them using market data. This quantitative approach has been usefully applied in other branches of economics, notably macroeconomics. Its main appeal is that it allows for quantitative comparisons between alternative theories. Given the multitude of theories in corporate finance together with the general lack of exogenous variation across firms facing any researcher attempting to do traditional empirical work, it seems likely that subsequent advances are likely to come from taking some of these models seriously and applying numerical methods to them.

\footnotetext{
${ }^{11}$ An interesting recent paper applying methods similar to ours that incorporates some of these factors is Titman and Tsyplacov (2001).
} 


\section{References}

Black, Fischer and John Cox, 1976, Valuing corporate securities: Some effects of bond indenture provisions, Journal of Finance 31, 351-367.

Brealey, Richard A. and Stewart C. Myers, 2000, Principles of Corporate Finance, $6^{\text {th }}$ Ed., Irwin McGraw-Hill (New York, NY).

Fischer, Edwin, Robert Heinkel and Josef Zechner, 1989, Dynamic capital structure choice: Theory and tests, Journal of Finance 44, 19-40.

Goldstein, Robert, Nengjiu Ju and Hayne Leland, 2001, An EBIT-based model of dynamic capital structure, Journal of Business 74, 483-512.

Graham, John R., 1996, Proxies for the corporate marginal tax rate, Journal of Financial Economics 42, $187-221$.

Graham, John R., 2000, How big are the tax benefits of debt?, Journal of Finance 55, 1901-1941.

Hamilton, David T., Greg Gupton, and Alexandra Berhault, 2001, Default and recovery rates of corporate bond issuers: 2000, (Moody's Investors Service).

Ingersoll, Johnathan E., 1987, Theory of Financial Decision Making, Rowman \& Littlefield (Savage, MD).

Jensen, Michael C. and William H. Meckling, 1976, Theory of the firm: Managerial behavior, agency costs and ownership structure, Journal of Financial Economics 3, 305-360.

$\mathrm{Ju}$, Nengjiu, 1998, Essays in corporate finance and derivatives pricing, Unpublished Ph.D. Dissertation, (University of California at Berkeley).

Ju, Nengjiu, 2001, Dynamic optimal capital structure and maturity structure, Unpublished manuscript, University of Maryland.

Kane, Alex, Alan J. Marcus and Robert L. McDonald, 1984, How big is the tax advantage to debt?, Journal of Finance 39, 841-852.

Kane, Alex, Alan J. Marcus and Robert L. McDonald, 1985, Debt policy and the rate of return premium to leverage, Journal of Financial and Quantitative Analysis 20, 479-499.

Leland, Hayne E., 1994, Corporate debt value, bond covenants, and optimal capital structure, Journal of Finance 49, 1213-1252.

Leland, Hayne E., 1998, Agency costs, risk management, and capital structure, Journal of Finance 53, 1213-1244.

Leland, Hayne E. and Klaus Toft, 1996, Optimal capital structure, endogenous bankruptcy, and the term structure of credit spreads, Journal of Finance 51, 987-1019.

Ljungqvist, Lars and Thomas J. Sargent, 2000, Recursive macroeconomic theory, The MIT Press (Cambridge, MA). 
Merton, Robert C., 1974, On the pricing of corporate debt: The risk structure of interest rates, Journal of Finance 29, 449-470.

Miller, Merton, 1977, Debt and taxes, Journal of Finance 32, 261-275.

Modigliani, Franco and Merton H. Miller, 1963, Corporate income taxes and the cost of capital: A correction, American Economic Review 53, 433-443.

Myers, Stewart C., 1977, Determinants of corporate borrowing, Journal of Financial Economics 5, 147175.

Myers, Stewart C., 1984, The capital structure puzzle, Journal of Finance 39, 575-592.

Myers, Stewart C. and Nicholas S. Majluf, 1984, Corporate financing and investment decisions when firms have information that investors do not have, Journal of Financial Economics 13, 187-221.

Rajan, Raghuram G. and Luigi Zingales, 1995, What do we really know about capital structure? Evidence from international data, Journal of Finance 50, 1421-1460.

Ross, Stephen A., Randolph W. Westerfield and Jeffrey Jaffe, 1999, Corporate Finance, $5^{\text {th }}$ Ed., Irwin McGraw-Hill (New York, NY).

Titman, Sheridan and Sergei Tsyplacov, 2001, A dynamic model of optimal capital structure, Working Paper, University of Texas at Austin and University of South Carolina.

Titman, Sheridan and R. Wessels, 1988, The determinants of capital structure, Journal of Finance 43, 119.

Welch, Ivo, 2002, Columbus' Egg: The real determinants of capital structure, NBER Working Paper No. 8782 . 
Table I

Model Parameters

\section{Panel A: Chosen Parameters}

\begin{tabular}{|c|c|c|}
\hline Variable & $\begin{array}{l}\text { Calibrated } \\
\text { Value }\end{array}$ & Variable Description \\
\hline$T_{u}$ & 1 & $\begin{array}{l}\text { Time at which manager evaluates utility and } \\
\text { options mature }\end{array}$ \\
\hline $\mathrm{T}$ & 10 & Time at which debt matures \\
\hline$r$ & 0.0522 & Annualized risk-free rate \\
\hline$V(0)$ & $\$ 100$ & Value of assets before swap \\
\hline$\mu$ & 0.1063 & Drift of value of firm assets \\
\hline$\sigma$ & 0.3802 & Volatility of value of firm assets \\
\hline$N_{N S}$ & 100 & Total shares outstanding before swap \\
\hline$\gamma$ & 2 & Manager's risk aversion parameter \\
\hline$N_{\text {Man }}$ & 0.32 & Number of shares owned by manager \\
\hline$N_{\text {Calls }}$ & 0.38 & $\begin{array}{l}\text { Number of exchange traded European calls } \\
\text { owned by manager }\end{array}$ \\
\hline$K$ & $\$ 1$ & Strike price of calls \\
\hline$N F W(0)$ & $\$ 0.32$ & $\begin{array}{l}\text { Manager's non-firm wealth in dollars at time } \\
\text { zero }\end{array}$ \\
\hline$\alpha_{B C}$ & 0.491 & 1 - Debtholder bankruptcy recovery rate \\
\hline $\mathrm{g}$ & 0.0369 & Bankruptcy boundary exponential growth rate \\
\hline$\tau$ & 0.34 & Effective tax rate for debt tax shield \\
\hline DivRate & 0.015 & $\begin{array}{l}\text { Dividend payout rate to equity holders as a } \\
\text { percentage of the unlevered value of the firm. }\end{array}$ \\
\hline
\end{tabular}


Table I (continued)

Model Parameters

\section{Panel B: Derived Variables}

\begin{tabular}{|c|c|}
\hline Variable & Variable Description \\
\hline$F_{S}$ & Face value of debt after swap \\
\hline$C_{S}$ & $\begin{array}{l}\text { Constant annualized coupon rate paid on debt } \\
\text { after swap. This is set to price the debt at par. }\end{array}$ \\
\hline$D_{s}(0)$ & Initial total value of debt after swap \\
\hline$N_{S}$ & Total shares outstanding after swap \\
\hline$E_{S}(0)$ & Initial total value of equity after swap \\
\hline$B C_{S}(0)$ & $\begin{array}{l}\text { Initial total value of bankruptcy costs after } \\
\text { swap }\end{array}$ \\
\hline$T B_{S}(0)$ & $\begin{array}{l}\text { Initial total value of tax benefits of debt after } \\
\text { swap }\end{array}$ \\
\hline$N F W\left(T_{u}\right)$ & Value of manager's non-firm wealth at time $T_{u}$ \\
\hline Utility(0) & $\begin{array}{l}\text { Expected future value of manager's utility } \\
\text { before swap }\end{array}$ \\
\hline Utilitys $_{S}(0)$ & $\begin{array}{l}\text { Expected future value of manager's utility after } \\
\text { swap }\end{array}$ \\
\hline$\phi$ & $\begin{array}{l}\text { Discounted risk-neutral expected value of the } \\
\text { quantity } V(T) / V(0)\end{array}$ \\
\hline$E_{S}^{\text {Dynamic }}(0)$ & Initial total value of equity after swap \\
\hline$B C_{S}^{\text {Dynamic }}(0)$ & $\begin{array}{l}\text { Initial total value of bankruptcy costs after } \\
\text { swap }\end{array}$ \\
\hline$T B_{S}^{\text {Dynamic }}(0)$ & $\begin{array}{l}\text { Initial total value of tax benefits of debt after } \\
\text { swap }\end{array}$ \\
\hline$\delta$ & $\begin{array}{l}\text { After tax cash payout rate to both debtholders } \\
\text { and equity holders as a percentage of the } \\
\text { unlevered value of the firm. }\end{array}$ \\
\hline$V^{K}\left(T_{u}\right)$ & $\begin{array}{l}\text { Value of assets that makes a share of stock } \\
\text { worth } K \text { dollars at time } T_{u}\end{array}$ \\
\hline
\end{tabular}


Table II

Model Output for Firms with Different Firm Asset Volatilities Where Objective is to Maximize Share Value

\begin{tabular}{|c|c|c|c|c|c|c|c|c|c|c|}
\hline \multicolumn{11}{|c|}{ Volatility of Firm Asset Value } \\
\hline Row & Variable & 0.1300 & 0.1800 & 0.2300 & 0.2800 & 0.3300 & 0.3802 & 0.4300 & 0.4800 & 0.5300 \\
\hline 1) & Debt/Total Capital After Swap & $39.56 \%$ & $31.84 \%$ & $25.91 \%$ & $21.25 \%$ & $17.50 \%$ & $14.42 \%$ & $11.89 \%$ & $9.74 \%$ & $7.91 \%$ \\
\hline & Equity: & & & & & & & & & \\
\hline 2) & Value of Equity Before Swap & $\$ 100$ & $\$ 100$ & $\$ 100$ & $\$ 100$ & $\$ 100$ & $\$ 100$ & $\$ 100$ & $\$ 100$ & $\$ 100$ \\
\hline 3) & Number of Shares Before Swap & 100 & 100 & 100 & 100 & 100 & 100 & 100 & 100 & 100 \\
\hline 4) & Value of Equity After Swap & $\$ 75.54$ & $\$ 81.82$ & $\$ 85.94$ & $\$ 88.73$ & $\$ 90.72$ & $\$ 92.22$ & $\$ 93.41$ & $\$ 94.42$ & $\$ 95.29$ \\
\hline 5) & Number of Shares After Swap & 60.44 & 68.16 & 74.09 & 78.75 & 82.50 & 85.58 & 88.11 & 90.26 & 92.09 \\
\hline 6) & Change in Share Price & $\$ 0.250$ & $\$ 0.201$ & $\$ 0.160$ & $\$ 0.127$ & $\$ 0.100$ & $\$ 0.078$ & $\$ 0.060$ & $\$ 0.046$ & $\$ 0.035$ \\
\hline & Debt: & & & & & & & & & \\
\hline 7) & Face Value of Debt After Swap & $\$ 49.44$ & $\$ 38.23$ & $\$ 30.05$ & $\$ 23.94$ & $\$ 19.24$ & $\$ 15.55$ & $\$ 12.60$ & $\$ 10.18$ & $\$ 8.18$ \\
\hline 8) & Value of Debt After Swap & $\$ 49.44$ & $\$ 38.23$ & $\$ 30.05$ & $\$ 23.94$ & $\$ 19.24$ & $\$ 15.55$ & $\$ 12.60$ & $\$ 10.18$ & $\$ 8.18$ \\
\hline 9) & Coupon After Swap & $\$ 2.636$ & $\$ 2.073$ & $\$ 1.666$ & $\$ 1.362$ & $\$ 1.129$ & $\$ 0.943$ & $\$ 0.792$ & $\$ 0.663$ & $\$ 0.551$ \\
\hline 10) & Bankruptcy Costs After Swap & $\$ 1.847$ & $\$ 2.563$ & $\$ 3.194$ & $\$ 3.706$ & $\$ 4.077$ & $\$ 4.298$ & $\$ 4.365$ & $\$ 4.288$ & $\$ 4.079$ \\
\hline 11) & Tax Benefit After Swap & $\$ 26.831$ & $\$ 22.614$ & $\$ 19.184$ & $\$ 16.373$ & $\$ 14.041$ & $\$ 12.065$ & $\$ 10.378$ & $\$ 8.888$ & $\$ 7.554$ \\
\hline
\end{tabular}




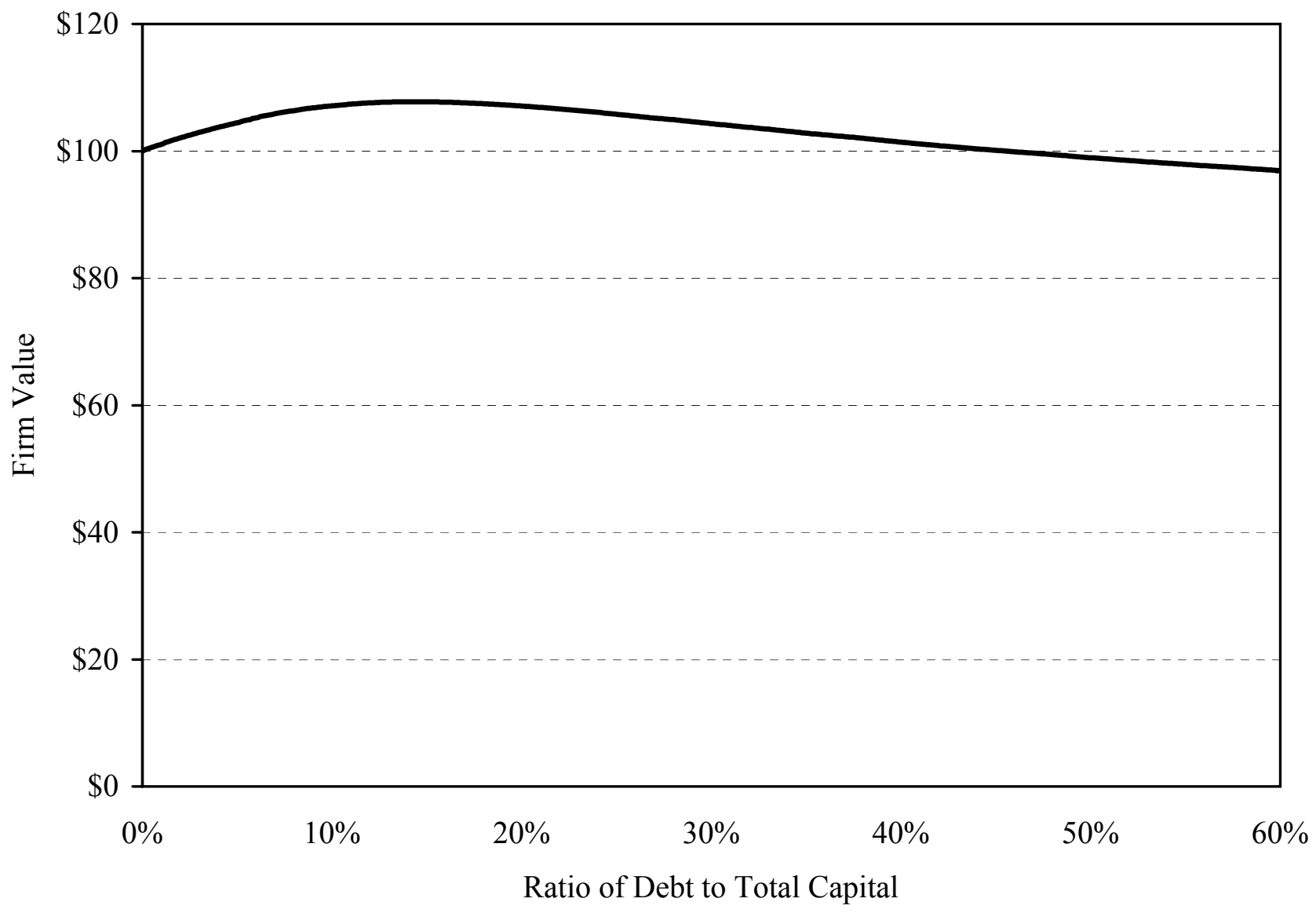

Figure 1. Firm value for different levels of debt financing. Values are estimated using a dynamic model in which the firm refinances maturing debt and that accounts for the impact of interest tax shields and bankruptcy costs associated on the total value of the levered firm. 


\section{Table III}

\section{Model Output for Firms with Different Firm Asset Volatilities Where Objective is to Maximize the Manager's Utility}

The values are for a manager with a risk aversion parameter of 2 , who owns 0.32 shares and 0.38 options on the firm's shares, and has non-firm wealth with a value equal to the value of 0.32 shares.

\begin{tabular}{|c|c|c|c|c|c|c|c|c|c|c|}
\hline \multicolumn{11}{|c|}{ Volatility of Firm Asset Value } \\
\hline Row & Variable & 0.1300 & 0.1800 & 0.2300 & 0.2800 & 0.3300 & 0.3802 & 0.4300 & 0.4800 & 0.5300 \\
\hline 1) & Debt/Total Capital After Swap & $38.92 \%$ & $30.38 \%$ & $23.87 \%$ & $18.74 \%$ & $14.61 \%$ & $11.25 \%$ & $8.54 \%$ & $6.33 \%$ & $4.85 \%$ \\
\hline & Equity: & & & & & & & & & \\
\hline 2) & Value of Equity Before Swap & $\$ 100$ & $\$ 100$ & $\$ 100$ & $\$ 100$ & $\$ 100$ & $\$ 100$ & $\$ 100$ & $\$ 100$ & $\$ 100$ \\
\hline 3) & Number of Shares Before Swap & 100 & 100 & 100 & 100 & 100 & 100 & 100 & 100 & 100 \\
\hline 4) & Value of Equity After Swap & $\$ 76.34$ & $\$ 83.54$ & $\$ 88.21$ & $\$ 91.41$ & $\$ 93.68$ & $\$ 95.36$ & $\$ 96.61$ & $\$ 97.57$ & $\$ 98.31$ \\
\hline 5) & Number of Shares After Swap & 61.08 & 69.62 & 76.13 & 81.26 & 85.39 & 88.75 & 91.46 & 93.67 & 95.45 \\
\hline 6) & Change in Share Price & $\$ 0.250$ & $\$ 0.200$ & $\$ 0.159$ & $\$ 0.125$ & $\$ 0.097$ & $\$ 0.075$ & $\$ 0.056$ & $\$ 0.042$ & $\$ 0.030$ \\
\hline & Debt: & & & & & & & & & \\
\hline 7) & Face Value of Debt After Swap & $\$ 48.63$ & $\$ 36.45$ & $\$ 27.66$ & $\$ 21.08$ & $\$ 16.03$ & $\$ 12.09$ & $\$ 9.02$ & $\$ 6.59$ & $\$ 4.69$ \\
\hline 8) & Value of Debt After Swap & $\$ 48.63$ & $\$ 36.45$ & $\$ 27.66$ & $\$ 21.08$ & $\$ 16.03$ & $\$ 12.09$ & $\$ 9.02$ & $\$ 6.59$ & $\$ 4.69$ \\
\hline 9) & Coupon After Swap & $\$ 2.587$ & $\$ 1.962$ & $\$ 1.512$ & $\$ 1.172$ & $\$ 0.909$ & $\$ 0.698$ & $\$ 0.531$ & $\$ 0.394$ & $\$ 0.284$ \\
\hline 10) & Bankruptcy Costs After Swap & $\$ 1.646$ & $\$ 2.040$ & $\$ 2.366$ & $\$ 2.558$ & $\$ 2.600$ & $\$ 2.498$ & $\$ 2.274$ & $\$ 1.957$ & $\$ 1.584$ \\
\hline 11) & Tax Benefit After Swap & $\$ 26.617$ & $\$ 22.029$ & $\$ 18.238$ & $\$ 15.045$ & $\$ 12.316$ & $\$ 9.949$ & $\$ 7.906$ & $\$ 6.121$ & $\$ 4.583$ \\
\hline
\end{tabular}


Table IV

Model Output for Firms with Different Tax Rates Where Objective is to Maximize Share Value

\begin{tabular}{|c|c|c|c|c|c|c|c|c|c|}
\hline \multirow[b]{2}{*}{ Row } & \multirow[b]{2}{*}{ Variable } & \multicolumn{8}{|c|}{ Tax Rate } \\
\hline & & $1 \%$ & $12 \%$ & $23 \%$ & $34 \%$ & $45 \%$ & $56 \%$ & $67 \%$ & $78 \%$ \\
\hline \multirow[t]{2}{*}{ 1) } & Debt/Total Capital After Swap & $2.24 \%$ & $7.42 \%$ & $11.11 \%$ & $14.42 \%$ & $17.42 \%$ & $20.13 \%$ & $22.57 \%$ & $24.84 \%$ \\
\hline & Equity: & & & & & & & & \\
\hline 2) & Value of Equity Before Swap & $\$ 100$ & $\$ 100$ & $\$ 100$ & $\$ 100$ & $\$ 100$ & $\$ 100$ & $\$ 100$ & $\$ 100$ \\
\hline 3) & Number of Shares Before Swap & 100 & 100 & 100 & 100 & 100 & 100 & 100 & 100 \\
\hline 4) & Value of Equity After Swap & $\$ 97.80$ & $\$ 94.02$ & $\$ 92.61$ & $\$ 92.22$ & $\$ 92.65$ & $\$ 93.83$ & $\$ 95.66$ & $\$ 98.05$ \\
\hline 5) & Number of Shares After Swap & $\$ 97.76$ & 92.58 & 88.89 & 85.58 & 82.58 & 79.87 & 77.43 & 75.16 \\
\hline \multirow[t]{2}{*}{ 6) } & Change in Share Price & $\$ 0.001$ & $\$ 0.016$ & $\$ 0.042$ & $\$ 0.078$ & $\$ 0.122$ & $\$ 0.175$ & $\$ 0.236$ & $\$ 0.305$ \\
\hline & Debt: & & & & & & & & \\
\hline 7) & Face Value of Debt After Swap & $\$ 2.24$ & $\$ 7.54$ & $\$ 11.58$ & $\$ 15.55$ & $\$ 19.55$ & $\$ 23.64$ & $\$ 27.89$ & $\$ 32.41$ \\
\hline 8) & Value of Debt After Swap & $\$ 2.24$ & $\$ 7.54$ & $\$ 11.58$ & $\$ 15.55$ & $\$ 19.55$ & $\$ 23.64$ & $\$ 27.89$ & $\$ 32.41$ \\
\hline 9) & Coupon After Swap & $\$ 0.117$ & $\$ 0.412$ & $\$ 0.666$ & $\$ 0.943$ & $\$ 1.249$ & $\$ 1.584$ & $\$ 1.949$ & $\$ 2.352$ \\
\hline 10) & Bankruptcy Costs After Swap & $\$ 0.017$ & $\$ 0.758$ & $\$ 2.241$ & $\$ 4.298$ & $\$ 6.778$ & $\$ 9.585$ & $\$ 12.715$ & $\$ 16.256$ \\
\hline 11) & Tax Benefit After Swap & $\$ 0.062$ & $\$ 2.314$ & $\$ 6.435$ & $\$ 12.065$ & $\$ 18.982$ & $\$ 27.052$ & $\$ 36.262$ & $\$ 46.713$ \\
\hline
\end{tabular}


Table V

Model Output for Firms with Different Bankruptcy Boundaries Where Objective is to Maximize Share Value

\begin{tabular}{|c|c|c|c|c|c|c|c|c|c|c|c|c|}
\hline & & & & & & & $\mathrm{g}$ & & & & & \\
\hline Row & Variable & $0 \%$ & $2 \%$ & $4 \%$ & $6 \%$ & $8 \%$ & $10 \%$ & $12 \%$ & $14 \%$ & $16 \%$ & $18 \%$ & $20 \%$ \\
\hline \multirow[t]{2}{*}{ 1) } & Debt/Total Capital After Swap & $11.82 \%$ & $13.19 \%$ & $14.66 \%$ & $16.21 \%$ & $17.87 \%$ & $19.64 \%$ & $21.55 \%$ & $23.65 \%$ & $26.04 \%$ & $28.98 \%$ & $33.45 \%$ \\
\hline & Equity: & & & & & & & & & & & \\
\hline 2) & Value of Equity Before Swap & $\$ 100$ & $\$ 100$ & $\$ 100$ & $\$ 100$ & $\$ 100$ & $\$ 100$ & $\$ 100$ & $\$ 100$ & $\$ 100$ & $\$ 100$ & $\$ 100$ \\
\hline 3) & Number of Shares Before Swap & 100 & 100 & 100 & 100 & 100 & 100 & 100 & 100 & 100 & 100 & 100 \\
\hline 4) & Value of Equity After Swap & $\$ 94.18$ & $\$ 93.17$ & $\$ 92.04$ & $\$ 90.79$ & $\$ 89.41$ & $\$ 87.87$ & $\$ 86.16$ & $\$ 84.20$ & $\$ 81.89$ & $\$ 78.95$ & $\$ 74.27$ \\
\hline 5) & Number of Shares After Swap & 88.18 & 86.81 & 85.34 & 83.79 & 82.13 & 80.36 & 78.45 & 76.35 & 73.96 & 71.02 & 66.55 \\
\hline \multirow[t]{2}{*}{ 6) } & Change in Share Price & $\$ 0.068$ & $\$ 0.073$ & $\$ 0.079$ & $\$ 0.084$ & $\$ 0.089$ & $\$ 0.093$ & $\$ 0.098$ & $\$ 0.103$ & $\$ 0.107$ & $\$ 0.112$ & $\$ 0.116$ \\
\hline & Debt: & & & & & & & & & & & \\
\hline 7) & Face Value of Debt After Swap & $\$ 12.62$ & $\$ 14.16$ & $\$ 15.81$ & $\$ 17.57$ & $\$ 19.45$ & $\$ 21.47$ & $\$ 23.66$ & $\$ 26.08$ & $\$ 28.83$ & $\$ 32.21$ & $\$ 37.33$ \\
\hline 8) & Value of Debt After Swap & $\$ 12.62$ & $\$ 14.16$ & $\$ 15.81$ & $\$ 17.57$ & $\$ 19.45$ & $\$ 21.47$ & $\$ 23.66$ & $\$ 26.08$ & $\$ 28.83$ & $\$ 32.21$ & $\$ 37.33$ \\
\hline 9) & Coupon After Swap & $\$ 0.736$ & $\$ 0.843$ & $\$ 0.963$ & $\$ 1.095$ & $\$ 1.241$ & $\$ 1.404$ & $\$ 1.588$ & $\$ 1.799$ & $\$ 2.052$ & $\$ 2.378$ & $\$ 2.912$ \\
\hline 10) & Bankruptcy Costs After Swap & $\$ 3.360$ & $\$ 3.856$ & $\$ 4.381$ & $\$ 4.930$ & $\$ 5.501$ & $\$ 6.093$ & $\$ 6.711$ & $\$ 7.365$ & $\$ 8.079$ & $\$ 8.913$ & $\$ 10.109$ \\
\hline 11) & Tax Benefit After Swap & $\$ 10.158$ & $\$ 11.182$ & $\$ 12.229$ & $\$ 13.289$ & $\$ 14.360$ & $\$ 15.438$ & $\$ 16.527$ & $\$ 17.639$ & $\$ 18.800$ & $\$ 20.073$ & $\$ 21.712$ \\
\hline
\end{tabular}


Table VI

Model Output for Firms with Different Bankruptcy Costs Where Objective is to Maximize Share Value

\begin{tabular}{|c|c|c|c|c|c|c|c|c|c|c|}
\hline \multirow[b]{2}{*}{ Row } & \multirow[b]{2}{*}{ Variable } & \multicolumn{9}{|c|}{ Bankruptcy Costs } \\
\hline & & $10 \%$ & $15 \%$ & $20 \%$ & $25 \%$ & $30 \%$ & $35 \%$ & $40 \%$ & $45 \%$ & $50 \%$ \\
\hline 1) & Debt/Total Capital After Swap & $24.84 \%$ & $22.58 \%$ & $20.74 \%$ & $19.20 \%$ & $17.91 \%$ & $16.81 \%$ & $15.85 \%$ & $15.03 \%$ & $14.30 \%$ \\
\hline & Equity: & & & & & & & & & \\
\hline 2) & Value of Equity Before Swap & $\$ 100$ & $\$ 100$ & $\$ 100$ & $\$ 100$ & $\$ 100$ & $\$ 100$ & $\$ 100$ & $\$ 100$ & $\$ 100$ \\
\hline 3) & Number of Shares Before Swap & 100 & 100 & 100 & 100 & 100 & 100 & 100 & 100 & 100 \\
\hline 4) & Value of Equity After Swap & $\$ 83.83$ & $\$ 85.78$ & $\$ 87.33$ & $\$ 88.57$ & $\$ 89.60$ & $\$ 90.45$ & $\$ 91.17$ & $\$ 91.78$ & $\$ 92.31$ \\
\hline 5) & Number of Shares After Swap & 75.16 & 77.42 & 79.26 & 80.80 & 82.09 & 83.19 & 84.15 & 84.97 & 85.70 \\
\hline 6) & Change in Share Price & $\$ 0.115$ & $\$ 0.108$ & $\$ 0.102$ & $\$ 0.096$ & $\$ 0.091$ & $\$ 0.087$ & $\$ 0.084$ & $\$ 0.080$ & $\$ 0.077$ \\
\hline & Debt: & & & & & & & & & \\
\hline 7) & Face Value of Debt After Swap & $\$ 27.71$ & $\$ 25.02$ & $\$ 22.84$ & $\$ 21.05$ & $\$ 19.55$ & $\$ 18.27$ & $\$ 17.18$ & $\$ 16.23$ & $\$ 15.40$ \\
\hline 8) & Value of Debt After Swap & $\$ 27.71$ & $\$ 25.02$ & $\$ 22.84$ & $\$ 21.05$ & $\$ 19.55$ & $\$ 18.27$ & $\$ 17.18$ & $\$ 16.23$ & $\$ 15.40$ \\
\hline 9) & Coupon After Swap & $\$ 1.591$ & $\$ 1.459$ & $\$ 1.348$ & $\$ 1.252$ & $\$ 1.170$ & $\$ 1.099$ & $\$ 1.037$ & $\$ 0.983$ & $\$ 0.935$ \\
\hline 10) & Bankruptcy Costs After Swap & $\$ 2.424$ & $\$ 3.113$ & $\$ 3.582$ & $\$ 3.893$ & $\$ 4.093$ & $\$ 4.213$ & $\$ 4.277$ & $\$ 4.300$ & $\$ 4.295$ \\
\hline 11) & Tax Benefit After Swap & $\$ 13.965$ & $\$ 13.916$ & $\$ 13.752$ & $\$ 13.514$ & $\$ 13.235$ & $\$ 12.933$ & $\$ 12.624$ & $\$ 12.315$ & $\$ 12.011$ \\
\hline
\end{tabular}


Table VII

Individual Firm Estimates

\begin{tabular}{|c|c|c|c|c|}
\hline \multirow[b]{2}{*}{ Company } & \multirow{2}{*}{$\begin{array}{l}\text { Volatility of } \\
\text { Asset Value }\end{array}$} & \multirow{2}{*}{$\begin{array}{c}\text { Actual Debt/Total } \\
\text { Capital }\end{array}$} & \multicolumn{2}{|c|}{ Estimated Debt/Total Capital } \\
\hline & & & $\begin{array}{c}\text { Value } \\
\text { Maximizing }\end{array}$ & $\begin{array}{c}\text { Utility } \\
\text { Maximizing }\end{array}$ \\
\hline \multicolumn{5}{|c|}{ Panel A: Wholesale Distribution Firms } \\
\hline Hughes Supply & 0.2767 & $56.36 \%$ & $21.35 \%$ & $19.66 \%$ \\
\hline Avnet & 0.3352 & $43.32 \%$ & $22.42 \%$ & $20.70 \%$ \\
\hline Tessco Technologies & 0.6251 & $7.37 \%$ & $5.60 \%$ & $4.07 \%$ \\
\hline Audiovox Corp. & 0.7060 & $8.46 \%$ & $8.49 \%$ & $6.44 \%$ \\
\hline Grainger (W.W.) & 0.7198 & $8.00 \%$ & $8.02 \%$ & $6.47 \%$ \\
\hline \multicolumn{5}{|c|}{ Panel B: Beer and Wine Manufacturing } \\
\hline Mondavi & 0.3369 & $29.21 \%$ & $14.58 \%$ & $12.82 \%$ \\
\hline Willamette & 0.3303 & $32.76 \%$ & $20.32 \%$ & $14.34 \%$ \\
\hline Pyramid Breweries & 0.3434 & $31.74 \%$ & $16.73 \%$ & $15.48 \%$ \\
\hline Golden State & 0.3301 & $35.52 \%$ & $19.24 \%$ & $18.23 \%$ \\
\hline Ravenswood & 0.4695 & $8.77 \%$ & $22.97 \%$ & $6.89 \%$ \\
\hline \multicolumn{5}{|c|}{ Panel C: Paper and Allied Products Manufacturing } \\
\hline Boise Cascade & 0.2795 & $48.19 \%$ & $15.39 \%$ & $12.74 \%$ \\
\hline Kimberly-Clark & 0.5387 & $6.24 \%$ & $7.22 \%$ & $4.45 \%$ \\
\hline Mead & 0.3768 & $30.75 \%$ & $49.98 \%$ & $15.06 \%$ \\
\hline P H Glatfelter & 0.3280 & $37.01 \%$ & $20.28 \%$ & $19.36 \%$ \\
\hline Wausau-Mosinee & 0.3553 & $30.90 \%$ & $15.37 \%$ & $13.58 \%$ \\
\hline
\end{tabular}




\section{Appendix}

In this appendix, we develop the dynamic model in more detail and then describe the procedure for computing the manager's utility at time $T_{u}$.

The Dynamic Model

To obtain $G(T), H(T)$, and $I(T)^{1}$ in (6), (7), and (8), we need the first passage time density

function. To this end, we define

$$
x(t) \equiv \log \left(\frac{V(t)}{F_{s} e^{-g(T-t)}}\right) .
$$

Then one simple application of Ito's lemma (under the risk-neutral measure) yields

$$
d x=\left(r-\delta-g-\sigma^{2} / 2\right) d t+\sigma d Z^{Q}(t) .
$$

Consequently, $x(t)$ is a Brownian motion with drift $m \equiv r-\delta-g-\sigma^{2} / 2$ and diffusion $\sigma$, starting at $x_{0}=\log \left(\frac{V(0)}{F_{s} e^{-g T}}\right)$. From Ingersoll (1987), the first-passage time density function $f(t)$ for crossing the origin is given by

$$
f(t)=\frac{x_{0}}{\sigma t^{3 / 2}} n\left(\frac{x_{0}+m t}{\sigma t^{1 / 2}}\right)
$$

where $n(\bullet)$ is the standard normal density function. Now lengthy but straightforward calculations yield ${ }^{2}$

$$
\begin{gathered}
G(T)=N\left[h_{1}(T)\right]+\left(\frac{V(0)}{F_{s} e^{-g T}}\right)^{-2 a} N\left[h_{2}(T)\right], \\
H(T)=\left(\frac{V(0)}{F_{s} e^{-g T}}\right)^{-a+z} N\left[q_{1}(T)\right]+\left(\frac{V(0)}{F_{s} e^{-g T}}\right)^{-a-z} N\left[q_{2}(T)\right],
\end{gathered}
$$

and

\footnotetext{
${ }^{1}$ For simplicity, we omit the other arguments of these functions.

${ }^{2}$ Explicit derivation is available upon request.
} 
where

$$
I(T)=\left(\frac{V(0)}{F_{s} e^{-g T}}\right)^{-a+\bar{z}} N\left[\bar{q}_{1}(T)\right]+\left(\frac{V(0)}{F_{s} e^{-g T}}\right)^{-a-\bar{z}} N\left[\bar{q}_{2}(T)\right]
$$

$$
\begin{gathered}
h_{1}(T) \equiv\left(\frac{-x_{0}-a \sigma^{2} T}{\sigma \sqrt{T}}\right), \quad h_{2}(T) \equiv\left(\frac{-x_{0}+a \sigma^{2} T}{\sigma \sqrt{T}}\right), \\
q_{1}(T) \equiv\left(\frac{-x_{0}-z \sigma^{2} T}{\sigma \sqrt{T}}\right), \quad q_{2}(T) \equiv\left(\frac{-x_{0}+z \sigma^{2} T}{\sigma \sqrt{T}}\right), \\
\bar{q}_{1}(T) \equiv\left(\frac{-x_{0}-\bar{z} \sigma^{2} T}{\sigma \sqrt{T}}\right), \quad \bar{q}_{2}(T) \equiv\left(\frac{-x_{0}+\bar{z} \sigma^{2} T}{\sigma \sqrt{T}}\right), \\
a \equiv \frac{\left(r-\delta-g-\sigma^{2} / 2\right)}{\sigma^{2}}, \quad \frac{\left[\left(a \sigma^{2}\right)^{2}+2 r \sigma^{2}\right]^{1 / 2}}{\sigma^{2}}, \quad \frac{-\bar{z} \equiv \frac{\left[\left(a \sigma^{2}\right)^{2}+2(r-g) \sigma^{2}\right]^{1 / 2}}{\sigma^{2}} .}{} .
\end{gathered}
$$

In these expressions, $N(\bullet)$ is the cumulative standard normal distribution function.

Given $G(T), H(T)$, and $I(T)$, the values of the debt, bankruptcy costs and tax benefits of the current debt are given by equations (10), (13), and (15), respectively. The total firm value in the static model, when debt is only sold by the firm one time, is given by the value of the firm's unlevered assets plus the tax benefit of debt (15) minus the bankruptcy cost (13)

$$
T V_{S}(0)=V(0)+T B_{S}(0)-B C_{S}(0)
$$

We now turn our attention to the dynamic model. In this model the firm optimally issues debt every $T$ years. Obviously, the optimal coupon for the second issue will depend on the firm value $V_{T}$ at time $T^{3}$ We note, however, the following scaling property: if the optimal coupon in the first period is $C_{S}$, then the optimal coupon in the second period will be $C_{S}\left(V_{T} / V_{0}\right)$. That is, the coupon is scaled by

\footnotetext{
${ }^{3}$ Here and below we sometimes write the time index on $V$ as a subscript, i.e., $V_{T}=V(T)$.
} 
$V_{T} / V_{0}$. The scaling property holds, because at time $T$ the firm is identical to itself at time zero, except that it is $V_{T} / V_{0}$ times as large. In fact, all future issues of debt will be scaled by the ratio of the firm's asset value when the debt matures to its asset value when the debt is issued.

Even though at time zero only the current issue of debt is outstanding, the tax benefits and bankruptcy cost reflect all future debt issues. Let $T B_{S}^{\text {Dynamic }}(0)$ denote the total tax benefit in the dynamic model. Then the scaling property discussed in the previous paragraph implies that the total tax benefit at time $T$ will be $T B_{S}^{\text {Dynamic }}(0)\left(V_{T} / V\right)$. If we now let $T B_{S}(0)$ denote the tax benefit from the initial issue of debt, we have

where

$$
T B_{S}^{\text {Dynamic }}(0)=T B_{S}(0)+e^{-r T} E^{Q}\left[\frac{V_{T}}{V} T B_{S}^{\text {Dynamic }}(0) \mid N B C\right]=T B_{S}(0)+\phi T B_{S}^{\text {Dynamic }}(0),
$$

$$
\phi=e^{-r T} E^{Q}\left[\frac{V_{T}}{V} \mid N B C\right]
$$

and " $N B C$ " denotes that there has been no bankruptcy yet by time $T$.

Equation (A9) states that the total tax benefit is the tax benefit for the first period, plus the riskneutral discounted total tax shield at the end of the first period. Solving for $T B_{S}^{\text {Dynamic }}(0)$, we obtain

$$
T B_{S}^{\text {Dynamic }}(0)=\frac{T B_{S}(0)}{1-\phi}
$$

The total tax shield has an intuitive series expansion. Each term in the expansion

$$
T B_{S}^{\text {Dynamic }}(0)=T B_{S}(0)\left(1+\phi+\phi^{2}+\phi^{3}+\cdots\right)
$$

evidently represents the present value of the tax benefit from the debt issue in each succeeding period.

To find $\phi$, we need the conditional distribution of $V_{T}$ such that the firm has not gone bankrupt at time T. Again, from Ingersoll (1987) we have the following conditional density function for $V_{T}$ : 


$$
\rho\left(V_{T}\right)=\frac{1}{V_{T} \sigma \sqrt{T}} n\left(\frac{x_{T}-x_{0}-m T}{\sigma \sqrt{T}}\right)-\frac{e^{\frac{2 m x_{0}}{\sigma^{2}}}}{V_{T} \sigma \sqrt{T}} n\left(\frac{x_{T}+x_{0}-m T}{\sigma \sqrt{T}}\right)
$$

Using the above density function, tedious but straightforward derivations yield the following closed form solution for $\phi$

$$
\phi=e^{-\delta T}\left(N\left(d_{1}\right)-\left(\frac{F_{s} e^{-g T}}{V}\right)^{2 \lambda} N\left(d_{2}\right)\right)
$$

where $\lambda=1+m / \sigma^{2}$ and

$$
d_{1}=\frac{-\log \left(F_{s} e^{-g T} / V\right)+\left(r-\delta-g+\sigma^{2} / 2\right) / T}{\sigma \sqrt{T}}, \quad d_{2}=\frac{\log \left(F_{s} e^{-g T} / V\right)+\left(r-\delta-g+\sigma^{2} / 2\right) / T}{\sigma \sqrt{T}}
$$

Similarly, the total bankruptcy cost in the dynamic model, $B C_{S}^{\text {Dynamic }}(0)$, is given by

$$
B C_{S}^{\text {Dynamic }}(0)=\frac{B C_{S}(0)}{1-\phi} .
$$

The total leveraged firm value, $T V_{S}^{\text {Dynamic }}(0)$, in the dynamic model equals the unleveraged firm value

$V(0)$, plus the total tax benefit $T B_{S}^{\text {Dynamic }}$, less the total bankruptcy cost $B C_{S}^{\text {Dynamic }}(0)$,

$$
T V_{S}^{\text {Dynamic }}(0)=V(0)+T B_{S}^{\text {Dynamic }}(0)-B C_{S}^{\text {Dynamic }}(0)=V(0)+\frac{T B_{S}(0)-B C_{S}(0)}{1-\phi}
$$

The optimal capital structure is obtained by maximizing either the total firm value or the manager's utility.

\section{The Manager's Utility at time $T_{u}$}

To compute the manager's utility at time $T_{u}$, we need to obtain the value of equity at $T_{u}$. We note that at $T_{u}$, part of the first period has passed. To determine the value of $E_{S}^{\text {Dynamic }}\left(T_{u}\right)$ at $T_{u}$, we first note that the total firm value at $T_{u}, T V_{S}^{\text {Dynamic }}\left(T_{u}\right)$, is the sum of the value of the equity and the debt at time $T_{u}$ :

$$
T V_{S}^{\text {Dynamic }}\left(T_{u}\right)=E_{S}^{\text {Dynamic }}\left(T_{u}\right)+D_{S}\left(T_{u}\right) .
$$


The debt $D_{S}\left(T_{u}\right)$ can be computed from equation (10) since its coupon $\left(C_{S}\right)$, face value $\left(F_{S}\right)$ and remaining maturity $\left(T-T_{u}\right)$, are all known. More specifically, $D_{S}\left(T_{u}\right)$ is obtained from equation (10) by making the followings replacements:

$$
T \rightarrow T-T_{u} \text { and } x_{0} \rightarrow x_{0}^{*}=\log \left(\frac{V_{T_{u}}}{F_{S} e^{-g\left(T-T_{u}\right)}}\right)
$$

Since $E_{S}^{\text {Dynamic }}\left(T_{u}\right)$ can be obtained from (A18) if $T V_{S}^{\text {Dynamic }}\left(T_{u}\right)$ and $D_{S}\left(T_{u}\right)$ are known, we need to determine $T V_{S}^{\text {Dynamic }}\left(T_{u}\right)$.

To compute $T V_{S}^{\text {Dynamic }}\left(T_{u}\right)$, we use the present value of the total cashflow $\left(\delta V_{t}+\tau C_{S}\right)$ from $T_{u}$ to $T$ and the present value at $T_{u}$ of the total firm value $T V_{S}^{\text {Dynamic }}(T)$ at $T$. From the scaling property, we have

Now

$$
T V_{S}^{\text {Dynamic }}(T)=T V_{S}^{\text {Dynamic }}(0) \cdot \frac{V_{T}}{V(0)}
$$

where

$$
\begin{aligned}
P V\left(T V_{S}^{\text {Dynamic }}(T)\right) & =e^{-r\left(T-T_{u}\right)} E_{T_{u}}\left[T V_{S}^{\text {Dynamic }}(0) \cdot \frac{V_{T}}{V(0)} \mid N B C\right] \\
& =e^{-r\left(T-T_{u}\right)} T V_{S}^{\text {Dynamic }}(0) \cdot \frac{V_{T_{u}}}{V(0)} E_{T_{u}}\left[\frac{V_{T}}{V_{T_{u}}} \mid N B C\right] \\
& =T V_{S}^{\text {Dynamic }}(0) \cdot \frac{V_{T_{u}}}{V(0)} \phi\left(T_{u}\right)
\end{aligned}
$$

$$
\phi\left(T_{u}\right)=E_{T_{u}}\left(\frac{V_{T}}{V_{T_{u}}} \mid N B C\right) e^{-r\left(T-T_{u}\right)},
$$

which is similar to the $\phi$ factor in equation (A14). Explicit calculation yields 


$$
\phi\left(T_{u}\right)=e^{-\delta\left(T-T_{u}\right)}\left(N\left(d_{1}\left(T_{u}\right)\right)-\left(\frac{F_{S} e^{-g\left(T-T_{u}\right)}}{V_{T_{u}}}\right)^{2 \lambda} N\left(d_{2}\left(T_{u}\right)\right),\right.
$$

where

$$
d_{1}\left(T_{u}\right)=\frac{\log \left(\frac{F e^{-g\left(T-T_{u}\right)}}{V_{T_{u}}}\right)+\left(r-\delta-g+\sigma^{2} / 2\right)\left(T-T_{u}\right)}{\sigma \sqrt{T-T_{u}}}
$$

and

$$
d_{2}\left(T_{u}\right)=\frac{-\log \left(\frac{F e^{-g\left(T-T_{u}\right)}}{V_{T_{u}}}\right)+\left(r-\delta-g+\sigma^{2} / 2\right)\left(T-T_{u}\right)}{\sigma \sqrt{T-T_{u}}} .
$$

Next we obtain the present value at $T_{u}$ of the cashflow $\left(\delta V_{t}+\tau C_{S}\right)$ from $T_{u}$ to $T$. Given the value $V_{T_{u}}$, which is random at time 0 ,

$$
\begin{aligned}
P V\left(\delta V_{t}+\tau C_{S}\right) & =\int_{T_{u}}^{T} e^{-r\left(t-T_{u}\right)} \int_{F_{S} e^{-g(T-t)}}^{\infty}\left[\delta V_{t}+\tau C_{S}\right] \rho\left(V_{t}\right) d V_{t} d t \\
= & \int_{0}^{T-T_{u}} e^{-r t^{*}} \int_{F_{S} e^{-g\left(F^{-t^{-*}}\right)}}^{\infty}\left[\delta V_{T_{u}+t^{*}}+\tau C\right] \rho\left(V_{T_{u}+t^{*}}\right) d V_{T_{u}+t^{*}} d t,
\end{aligned}
$$

where $t^{*}=T_{u}+t$. The inner integral is similar to the $\phi$ factor in equation (A23). It follows that

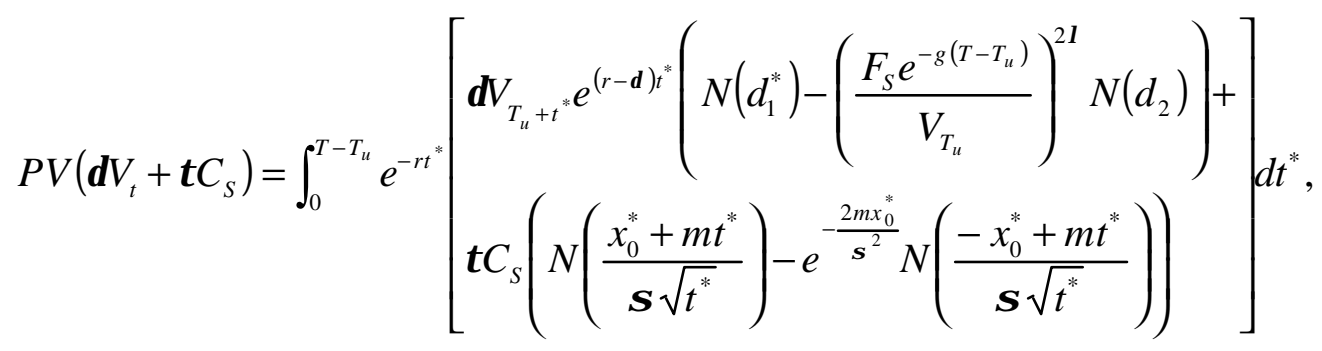

where

$$
x_{0}^{*}=\log \left(\frac{V_{T_{u}}}{F_{S} e^{-g\left(T-T_{u}\right)}}\right) \text {, }
$$




$$
\begin{aligned}
& d_{1}^{*}=\frac{x_{0}^{*}+\left(r-\delta-g+\frac{\sigma^{2}}{2}\right)^{*}}{\sigma \sqrt{t^{*}}}, \\
& d_{2}^{*}=\frac{-x_{0}^{*}+\left(r-\delta-g+\frac{\sigma^{2}}{2}\right) t^{*}}{\sigma \sqrt{t^{*}}} .
\end{aligned}
$$

Although the derivation is tedious, the time integrals can be done in closed form yielding

$$
P V\left(\delta V_{t}+\tau C\right)=V_{T_{u}}\left(I_{1}^{*}-\left(\frac{F e^{-g\left(T-T_{u}\right)}}{V_{T_{u}}}\right)^{2 \lambda} I_{2}^{*}\right)+\frac{\tau C_{S}}{r}\left(I_{3}^{*}-e^{-\frac{2 m x_{0}^{*}}{\sigma}} I_{4}^{*}\right),
$$

where

$$
\begin{aligned}
& I_{1}^{*}=I\left(x_{1}, x_{2}, x_{3} ; T-T_{u}\right): x_{1}=-\delta, x_{2}=\frac{r-\delta-g+\frac{\sigma^{2}}{2}}{\sigma}, x_{3}=\frac{x_{0}^{*}}{\sigma}>0, \\
& I_{2}^{*}=I\left(x_{1}, x_{2}, x_{3} ; T-T_{u}\right): x_{1}=-\delta, x_{2}=\frac{r-\delta-g+\frac{\sigma^{2}}{2}}{\sigma}, x_{3}=-\frac{x_{0}^{*}}{\sigma}<0, \\
& I_{3}^{*}=I\left(x_{1}, x_{2}, x_{3} ; T-T_{u}\right): x_{1}=-r, x_{2}=\frac{r-\delta-g-\frac{\sigma^{2}}{2}}{\sigma}, x_{3}=\frac{x_{0}^{*}}{\sigma}>0, \\
& I_{4}^{*}=I\left(x_{1}, x_{2}, x_{3} ; T-T_{u}\right): x_{1}=-r, x_{2}=\frac{r-\delta-g-\frac{\sigma^{2}}{2}}{\sigma}, x_{3}=-\frac{x_{0}^{*}}{\sigma}<0,
\end{aligned}
$$

and the $I\left(x_{1}, x_{2}, x_{3} ; t\right)$ function is defined as,

$$
\begin{aligned}
I\left(x_{1}, x_{2}, x_{3} ; t\right)= & e^{x_{1} t} N\left(x_{2} \sqrt{t}+x_{3} / \sqrt{t}\right)-1\left(x_{3}>0\right) \\
& -\frac{1}{2}\left(\frac{x_{2}}{x_{4}}+1\right) e^{x_{3}\left(x_{4}-x_{2}\right)}\left(N\left(x_{4} \sqrt{t}+x_{3} / \sqrt{t}\right)-1\left(x_{3}>0\right)\right) \\
& -\frac{1}{2}\left(\frac{x_{2}}{x_{4}}-1\right) e^{-x_{3}\left(x_{4}+x_{2}\right)}\left(N\left(x_{4} \sqrt{t}-x_{3} / \sqrt{t}\right)-1\left(x_{3}<0\right)\right) .
\end{aligned}
$$

$N(\bullet)$ is the normal distribution function, $1(\bullet)$ is the indicator function, and $x_{4}=\sqrt{x_{2}^{2}-2 x_{1}}$. 